Tomasz Szkudlarek

Uniwersytet Gdański

E-MAIL: pedts@ug.edu.pl

Karolina Starego

Uniwersytet Gdański

E-MAIL: karolina.starego@ug.edu.pl

\title{
Ontologie polityczności, polityki utożsamienia. Profesor Tomasz Szkudlarek w rozmowie z doktor Karoliną Starego
}

\begin{abstract}
STRESZCZENIE
Rozmowa dotyczy polityczności edukacji oraz politycznego charakteru teorii edukacyjnej. Rozmówcy skupiają się na wymiarze tożsamościowym i identyfikacyjnym podejmowanej problematyki. Kluczowe dla tegoż zagadnienie performatywności edukacyjnej retoryki oraz ontologii teorii edukacyjnej rozwijane jest w perspektywie politycznej koncepcji Ernesta Laclau oraz w kontekście współczesnych zjawisk społecznych i politycznych, takich jak transformacja ustrojowa, zagrożenie autorytaryzmem oraz faszyzacja przestrzeni publicznej.

SŁowA KluCzowe: polityczność edukacji, ontologia polityczności, Ernesto Laclau, retoryka, identyfikacja
\end{abstract}

Karolina Starego: Nie wyobrażam sobie rozpoczęcia naszej rozmowy na temat polityczności i politycznych kontekstów edukacji bez pytania o Twoją nową książkę, On the Politics of Educational Theory: Rhetoric, theoretical ambiguity, and the construction of society (Theorizing Education), która ukazała się w ubiegłym roku nakładem Wydawnictwa Routlege. W centrum jej zainteresowania stoi pytanie o polityczność teorii edukacyjnych właśnie. Odpowiedź nie jest ani oczywista, ani prosta, przeciwnie, uderzająca jest tu nowatorskość i błyskotliwość w ujęciu problemu. W książce pojawiają się bowiem skrupulatne analizy wybranych - znanych, ale ukazanych w całkowicie nowym świetle - teorii edukacyjnych, będących egzemplifikacją omawianego szerszego zjawiska ich politycznej sprawczości. Teorie edukacyjne traktowane są tu zatem jako maszyny ontologiczne, odpowiedzialne nie tylko za kształt aktualnej społecznej rzeczywistości, ale za warunek możliwości społecznego porządku w ogólności. Tym, co mnie w pierwszym rzędzie interesuje, to droga, która doprowadziła do takiego ujęcia problemu polityczności edukacji. 
Sporo się bowiem zmieniło od pojawienia się wcześniejszej książki, w której polityczność rozumiana była jeszcze w oparciu o teorię krytyczną, a więc jako wynik uwikłania, i w efekcie podporządkowania edukacji szerszym od niej procesom społecznym. W nowym ujęciu dokonała się bez wątpienia pewna emancypacja edukacji, odpowiedzialnej teraz za kształt społecznej obiektywności. W pierwszym rzędzie zatem chciałabym zapytać o to, jak w ogóle doszło do takiego ujęcia problemu?

Tomasz Szkudlarek: Starałem się po prostu testować te podejścia. Fakt, że skupiłem się w tej książce na teoriach, nie był pomyślany jako sygnał, że praktyki edukacyjne nie są istotne. To byłoby zwyczajnie niemądre. Krótko mówiąc, ta książka nie jest dyskusją z tym, co dzieje się w obszarze praktyk edukacyjnych. To po prostu inny temat.

Jest tu natomiast jakiś związek, czy też przejście między tymi obszarami. Łącznikiem są badania nad dyskursem, które kiedyś wspólnie prowadziliśmy w dużym projekcie badawczym. Zarówno praktyki, jak teorie mogą być analizowane jako elementy dyskursu edukacyjnego, czyli zarazem dyskursu publicznego. W tej perspektywie teorie, tak samo jak praktyki, wpisują się w proces konstruowania rzeczywistości; są - potencjalnie - aktywną siłą, która coś w społecznej rzeczywistości wytwarza. Takie podejście ma oczywiście swoją historię. Może nawet zaprzeszłą, bo moje uwrażliwienie na to, że teorie mogą być siłą polityczną, wzięło się po prostu z doświadczenia PRL-u. $\mathrm{Z}$ tego, że teorie były wtedy traktowane jako politycznie istotne, że polityczne kryteria powodowały, że na przykład jedne z nich były, a inne nie były publikowane. To znaczy, że teorie wiązały się z jakimiś nadziejami albo z jakimś lękiem co do ontologicznych skutków posługiwania się takim czy innym językiem. Krótko mówiąc, w tamtej PRL-owskiej rzeczywistości teoria była traktowana jako dyskurs w zupełnie współczesnym sensie tego pojęcia.

W książce, o której mówisz chciałem pokazać, że nie dotyczy to bynajmniej tylko i wyłącznie PRL-u, chociaż jeden z takich wątków z moich starych analiz dotyczących PRL-owskiej pedagogiki musiałem tam umieścić, żeby jakoś spiąć te intuicje. Ale generalnie chodziło mi o to, że ontologiczne znaczenie teorii, to znaczy zdolność teorii do wytwarzania politycznych rzeczywistości po prostu przez to, że są elementem języka publicznego, nie dotyczy tylko i wyłącznie jakichś reżimów totalitarnych czy autorytarnych, które przez cenzurę próbują regulować sposoby tworzenia świata; że jest to po prostu pewna, być może immanentna, cecha dyskursu edukacyjnego, który jest zawsze uwikłany w projekt naprawy czy zmiany świata. To niewątpliwie cecha modernizmu, gdzie samo mówienie o tym, że społeczeństwo powinno być inne niż jest, stanowi element procesu społecznej zmiany. W społeczeń- 
stwach republikańskich to właśnie mówienie - a tym bardziej pisanie - performatywnie wytwarza społeczne rzeczywistości. Bardzo wyraźnie jest to widoczne w dzisiejszej Polsce. Teorie są częścią tego procesu - i jest to proces sięgający co najmniej XVIII wieku. Dlatego mogłem zacząć swoje analizy od Rousseau. W tym kontekście przeciwstawianie teorii i praktyk edukacyjnych nie jest takie istotne.

K.S.: Interesujące jest również to, że stanowiąca metodologiczną postawę tych analiz teoria Ernesto Laclau przybiera całkowicie nową postać. Zostaje rozwinięta o element normatywny, kluczowy z punktu widzenia analiz skoncentrowanych na teoriach edukacyjnych. Zamiar nadania tej koncepcji politycznej charakteru deontologicznego pojawił się już we wcześniejszych Twoich tekstach. W książce jednak mamy już do czynienia z w pełni rozwiniętą koncepcją. Jak wyglądało przejście od teorii politycznej do edukacji wywołującej efekty polityczne?

T.S.: Ojej, to długa historia. Po pierwsze, teoria Laclau jest dla mnie cały czas niesłychanie istotną matrycą myślową. Nie znam chyba bardziej przekonującej teorii społecznej traktującej o konstruowaniu rzeczywistości w praktykach politycznych, czy generalnie w praktykach dyskursywnych, bo wszystko co polityki dotyczy przede wszystkim koncentruje się wokół mowy, pisma, mówienia, wypowiedzi, performatywów zawartych w rozmaitych wypowiedziach: nakazuję, zakazuję, skazuję, oświadczam, niniejszym uznaję za otwarte i tak dalej. Po prostu te rzeczywistości polityczne wytwarzane są w komunikacji między ludźmi i Laclau zrobił niesamowitą rzecz, pokazując, że retoryka nie jest tu tylko siłą perswazyjną, co zawsze było wiadomo. Cała historia kształcenia polityków od czasów antycznych bardzo duży nacisk kładła na retorykę. Jednak w politycznej retoryce nie chodzi tylko o to, żeby kogoś przekonać, nawet wtedy, kiedy samemu nie jest się przekonanym do tego co się mówi. Chodzi także o to, że przy pomocy środków retorycznych konstruujemy to, czego skonstruować się nie da, co nigdy nie zostanie osiągnięte, co jest stale nieobecnym i ciągle pożądanym fundamentem życia społecznego - czyli po prostu wspólnotę. I to wspólnotę rozumianą w sposób radykalny, bez którego nie byłoby w ogóle polityki. Bo gdybyśmy mówili po prostu tylko na takim poziomie normatywnym, empirycznym, związanym z doświadczeniem codzienności - no to do czegoś takiego żadnej polityki nie trzeba, wystarczy, że ludzie są sąsiadami i w jakiś sposób współpracują czy rywalizują, jakieś wspólnoty wytwarzają wtedy niemal naturalnie. Natomiast tutaj chodzi o wspólnotę rozumianą jako pewnego rodzaju totalność, jako „my wszyscy”, jako pewien taki naddatek symboliczny, który po prostu nijak nie może być reprezentowany przy pomocy normalnych pojęć, normalnych 
perswazji, normalnych argumentów. „My wszyscy”, społeczna totalność, naród czy społeczeństwo, które są zakładanym w republikańskich projektach podmiotem polityki, wręcz jej suwerenem, od zawsze mają i zawsze mieć będą wymiar symbolicznej pustki. Laclau mówi wprost, że nie istnieją; genialnie pokazuje, jak mimo tej pustki, mimo nieistnienia przedmiotu odniesienia symboli politycznej totalności, przy pomocy retoryki przejętej z tradycji religijnej skutecznie buduje się przekonujące wizje społecznej totalności. Co więcej, Laclau pokazuje, w jaki sposób to się konstruuje krok po kroku, stopniowo, w jaki sposób ten proces budowania totalności jest zagnieżdżony w praktykach formowania tożsamości zaczynających się od sąsiedztwa pewnych społecznych żądań, jakiejś prostej i często przypadkowej ich styczności, od której przechodzimy do problemu wspólnej reprezentacji: do pytania o to, jak to, co nas w określonym momencie sprzeciwu połączyło przedstawić jako całość, jako totalność, jako „my naród” albo „wszyscy Polacy”. I tu mamy te wszystkie retoryczne zabiegi, stopniowe przejścia od styczności na zasadzie metonimii do synekdochy, która jedno ze szczegółowych żądań - jak to dotyczące stworzenia niezależnego związku zawodowego w roku 1980 - „wynosi do godności Rzeczy", czyni z niego synekdochę reprezentującą naród. I to cały czas jest dla mnie niezwykle ważne, i właściwie bez tej teorii całego projektu, o którym rozmawiamy by nie było. To od Laclau wiem, że nie tylko - a wręcz nie tyle - konstrukcja ogólnych pojęć, ile retoryka ma sens ontologiczny, że to retoryka stwarza struktury społeczne. Dlatego analizuję teksty teoretyczne nie tylko $\mathrm{w}$ ich wymiarach pojęciowych, ale łącznie $\mathrm{z}$ ich strategiami retorycznymi.

Natomiast są takie dwa punkty w teorii Laclau, które są dyskusyjne. Jeden jest dyskusyjny, że tak powiem, politycznie, a drugi pedagogicznie. Ta polityczna dyskusyjność teorii Laclau była najmocniej formułowana przez Simona Critchleya, który mówił, że ta teoria zawiera pewien „deficyt normatywny”. Jemu chodziło po prostu o to, że o ile ona świetnie opisuje to co już się stało, czyli na przykład historie ruchów populistycznych, o tyle są trudności z jej przełożeniem na praktyki polityczne, szczególnie w tych obszarach, które i Laclau, i Critchleya najbardziej interesują, czyli projekty nowej polityki lewicowej. W tle mamy oczywiście pewien kryzys wielkich utopii społecznych, socjalizmu i tak dalej, i impotencję bieżącej polityki, która mogłaby się przeciwstawić prawicowemu populizmowi. Critchley uporczywie powtarzał pytania o to, w jaki sposób od ontologiczności tej teorii przejść do bieżących praktyk walki politycznej czy kampanii politycznych. Mnie się wydaje, że Critchley nie docenia tej teorii, a także nie docenia sprytu niektórych ekspertów, bo to co ja widzę w obecnej polityce PiS-u wydaje się pokazywać, że 
ludzie tej partii wiedzą, jak to zrobić. Prawdopodobnie Andrzej Zybertowicz, który jest oczytanym człowiekiem i pełni funkcje doradcze obecnej władzy, a może też inni eksperci jego formatu, potrafią przełożyć wizję fundamentalnej pustki, jaką jest całość społeczna, na praktyki retoryczne, które służą jej konstruowaniu. To się naprawdę daje zrobić. Ale mniejsza o Critchleya i o źródła retorycznego sukcesu PiS; w każdym razie kwestia „normatywnego deficytu" to miejsce, w którym Laclau wielokrotnie był atakowany, czy może upominany; oczekiwano, że coś z tym problemem zrobi. Jego odpowiedzi konsekwentnie były mniej więcej takie, że cała ta brakująca strefa normatywności jest już poza zakresem jego teorii. Że to jest po prostu normatywność konkretnego kontekstu społecznego, w którym społeczeństwa są konstruowane, i na tej zasadzie „wyskakuje” ona poza strukturalny schemat jego teorii. Krótko mówiąc, kontekst normatywny jest bardzo ważny, ale w każdym społeczeństwie wygląda on inaczej. Ludzie generalnie wiedzą, jak to wygląda, bo po prostu żyją w jakichś wspólnotach.

Natomiast jeden ze szczegółowych argumentów, jakie Laclau proponował w tej dyskusji, był dla mnie bardzo ciekawy, bo pokazywał coś, czego teoria Laclau nie chwyta - po prostu dlatego, że ignoruje dyskurs pedagogiczny jako istotną część ontologicznej konstrukcji tożsamości politycznych (no i teraz już wiadomo, po co pisałem tę książkę; chciałem ten "pedagogiczny suplement” pokazać w działaniu). Nieco ironizując, Laclau mówił, że Critchley wyobraża sobie, że konstruowanie społeczeństw polega na tym, że mamy jakąś abstrakcję, jakieś założenia etyczne czy ideologiczne, i z tych założeń sobie wyprowadzamy jakieś normatywne reguły, które miałyby odpowiadać tym założeniom i mogłyby być „wcielone w życie”; że najpierw mamy po prostu jakiś konstrukt społecznej totalności i z tej retorycznej konstrukcji wyprowadzamy sobie szczegółowe reguły funkcjonowania społeczeństwa. Odpowiedź Laclau przeciw Critchleyowi jest taka, że jest to stawianie problemu na głowie, bo nie jest tak, że z wymiaru ontologicznego czy etycznego (dla Laclau etyka sytuuje się na tym samym poziomie co ontologia, operują one semantycznie pustymi terminami), no więc że możemy sobie z tego poziomu etycznego przejść do poziomu normatywnego na zasadzie pewnego rodzaju dedukcji, wyprowadzenia konsekwencji, i stworzyć sobie jakąś przestrzeń normatywną, która będzie wcielać te fundamentalne dla nas wartości. Tak się po prostu nigdy nie dzieje, proces jest raczej odwrotny; normatywna (ontyczna) sfera zawsze już istnieje, problemem jest tylko to, jak można ją reprezentować jako całość i totalność.

No i teraz ja. Cały dowcip moim zdaniem polega na tym, że to, co $\mathrm{w}$ polityce jest niemożliwe, w instytucjach edukacyjnych właśnie jest moż- 
liwe. Krótko mówiąc, szkoły można konstruować w oparciu o abstrakcyjne, etyczne czy ontologiczne założenia. Można skonstruować mnogość systemów normatywnych, które wydają nam się wcielać tego typu założenia, wprowadzić w takie miejsca ludzi i zmusić ich do funkcjonowania według tego wynalezionego typu normatywności. Oczywiście w przestrzeni politycznej tego się nigdy nie da osiągnąć, bo żadne totalne czy totalitarne społeczeństwo nie jest kompletne. Żadnemu totalitaryzmowi nie udaje się zagarnąć całości życia społecznego. Szkole oczywiście też nie, ale szkoła ma jedną istotną cechę, o której chętnie dziś zapominamy - jest ona oddzielona murami od „normalnej" normatywności społeczeństwa. W społeczeństwie rywalizacyjnym może uczyć koooperacji, a w kooperacyjnym rywalizacji, i tak dalej. W każdym razie, ta figura przejścia od etyczności do normatywności i od normatywności do określonego typu praktyk, które mogą być w dodatku egzekwowane na poziomie zachowań, czyli stają się normatywnością doświadczaną, przeżywaną, mają swoje sankcje, regulaminy, kary, nagrody i tym podobnie - nie jest jakąs fikcją. W edukacji po prostu można to próbować robić. To jest wręcz pedagogicznie oczekiwane. Szkoła może funkcjonować jako laboratorium potencjalnych rzeczywistości, w którym można eksperymentować z nieistniejącymi światami. I generalnie taka właśnie była idea politycznych funkcji szkoły w epoce tworzenia systemów edukacji publicznej. W wymiarze politycznym szkoła jest dokładnie po to, żeby świat był inny niż jest; po to, żeby zerwać z normatywnością zastaną i przeprogramować normatywność, to co wolno i czego nie wolno, co wypada i czego nie wypada, co wiadomo i czego nie wiadomo - a z tym cały proces konstrukcji społeczeństwa - w stronę zbliżającą nas do jakiegoś rodzaju utopii. Na tym zasadza się przecież cały dyskurs modernizacji.

Książka, o którą pytasz jest osadzona w tej problematyce. Jest próbą pokazania, że właśnie myślenie edukacyjne jest jakiegoś rodzaju ontologiczną retoryką konstruowania rzeczywistości społecznych. Że może retoryczna konstrukcja społeczeństwa to coś jeszcze szerszego niż mówi Laclau, że niekoniecznie musi ograniczać się do procesu reprezentacji, czy do trudności z reprezentacją całości poharatanego świata, w którym żyjemy, do poszukiwania pełni i pokoju, społecznego porozumienia. Laclau nazywa to w pełni pojednanym społeczeństwem. Krótko mówiąc, to nie jest tylko kwestia tego, jak sobie wyobrazimy przejście od chaosu, który mamy, do wytęsknionego porządku. Myślenie edukacyjne zawiera też bardzo wyraźnie element zainwestowania jakiejś nadziei w określoną wizję tego innego porządku i próby wytwarzania mechanizmów normatywnych, które będą ten porządek ściągać, że tak powiem - na glebę. I oczywiście nie mam zamiaru dowodzić, że edu- 
kacja jest w tym skuteczna, bo to się zwyczajnie nie może udać z tego względu, że żadne działanie techniczne nie realizuje swoich założeń. Dlaczego akurat edukacyjne miałoby być doskonałe? I tu znowu - na innym poziomie niż ten opisywany przez Laclau - pojawia się miejsce na retoryki, które muszą wypełniać te deficyty konceptualnej pełni, technologicznej sprawczości i tak dalej, i tak dalej. Te właśnie retoryki próbuję śledzić w teoriach, próbuję pokazywać, w jaki sposób konstruują one warunki możliwości zrealizowania tego typu projektów. To najpełniej, najwyraźniej widać w tekstach Rousseau, które budują liczne dystynkcje między widzialnością a niewidzialnością określonych działań edukacyjnych. Tak samo zresztą jak politycznych. Rousseau jest tutaj konsekwentny i tak samo pisze o polityce, jak o edukacji. Dystynkcja widzialności i niewidzialności jest głównym ontologicznym wymiarem konstrukcji sceny, na której to wszystko, co zaprojektujemy jako praktyki pedagogiczne czy strategie polityczne w ogóle może się zadziać. W tym sensie patrzę na to jako na retoryki ontologiczne, konstruowanie niewidzialności jest jedną z podstawowych. A poza tym, po części na poziomie - nazwijmy to - ontycznym, bezpośrednio dostępnym oglądowi, retoryka musi po prostu łatać dziury w argumentacji logicznej, sprzeczności w konceptualnej konstrukcji teorii. U Rousseau jest ich pełno. Czyli tam, gdzie mamy konceptualne nieciągłości, gdzie wikłamy się w paradoksy i tak dalej, uruchamiamy cały arsenał środków retorycznych, za pomocą których teksty pedagogiczne można uczynić tekstami spójnymi i przekonującymi. Ten czysto techniczny wymiar ma jednak także sens ontologiczny - służy retorycznej konstrukcji totalności, która - jak mówi Laclau - ontologicznie jest niemożliwa, ale politycznie konieczna. Tych toposów i retorycznych strategii jest znacznie więcej, i mimo że próbuję je uchwycić jako jakiś model, to on oczywiście będzie pękać wielokrotnie, w wielu miejscach. W jednej teorii działa jeden element, w innej drugi, przesuwają się, służą różnym celom i tak dalej. Zresztą żaden tekst nie jest kompletny i teorie nie są wcale w jakiejś uprzywilejowanej sytuacji. Gdy się je czyta w całości - nie tylko na poziomie strukturalnych szkieletów, ale razem z całym językowym bałaganem i usuwającymi go z pola widzenia dyskursywnymi zabiegami - okazują się zaskakująco bogate i wielowymiarowe, bardzo im daleko do podręcznikowej klarowności.

K.S.: Zatrzymajmy się na moment przy zagadnieniu teorii edukacyjnej, która bierze udział w konstruowaniu rzeczywistości. Rzeczywiście, nawet powierzchowny wgląd w zróżnicowane dyskursy publiczne oraz polityczne pokazuje ich pedagogiczny charakter. Wydaje się zatem, że dyskurs edukacyjny jest stale obecny. Weźmy za przykład rodzimy kontekst. Najpierw okres PRL-u, potem transformacja, neoliberalizm, od jakiegoś czasu pra- 
wicowy backlash i nacjonalistyczna kontrofensywa. Wydaje się, że jesteśmy w nieustannym procesie tworzenia czy konstruowania nowej rzeczywistości. Jest $\mathrm{w}$ tym pewien ciekawy problem. $\mathrm{Z}$ jednej strony mówimy bowiem o odrodzeniu się myślenia konserwatywnego, z drugiej natomiast, proces tworzenia czy wytwarzania rzeczywistości nie jest w swojej istocie konserwatywnym zjawiskiem. Zastanawiam się, jak to jest w ogólne możliwe. Czy modernistyczny dyskurs, z którym nieustannie mamy do czynienia, a w którym teoria edukacyjna odgrywa bardzo istotną, wręcz fundamentalną rolę, nie wyklucza konserwatyzmu? Czy w takiej perspektywie konserwatyzm $\mathrm{w}$ ogólne jest możliwy? Z czym w takim razie, ideologicznie rzecz biorąc, mamy obecnie do czynienia? Nie chodzi o to, że jakoś specjalnie troszczę się o konserwatyzm, ale również, mimo progresywności dyskursu edukacyjnego, nie widzę na horyzoncie jakiejś uderzającej przewagi dyskursu lewicowego czy bardziej postępowego.

T.S.: To jest jedno z najważniejszych pytań dla zrozumienia tego, co się dzieje. I oczywiście ja tego nie rozumiem, ale uznaję wagę tego pytania. Bo ono naprawdę trafia w coś, co się odczuwa jako pewnego rodzaju fundamentalny zgrzyt, na poziomie konstrukcji pojęciowych i retoryk, którymi te koncepcje są jakby opakowywane w dyskursie publicznym w dzisiejszej Polsce. Ale oczywiście nie tylko w Polsce. Wydaje mi się, że tutaj parę rzeczy można by było rozważyć. Pierwsza to ta, że konserwatyzm i radykalizm to są kryteria $z$ innych par opozycji. Przywykliśmy do tego, że radykalizm wiąże się z lewicowością, z progresywizmem, z wizjami przyszłości, które wybiegają w stronę jakiegoś ideału i tak dalej. No i generalnie zawsze zagospodarowywała to tak zwana lewica, a ze względu na opór wobec takich wielkich projektów, na to, że ludzie nie wiedzą, nie wyobrażają sobie, nie wierzą, i tak dalej, takie myślenie radykalizuje się i wymaga jakichś gwałtownych środków. W tej puli środków zawsze gdzieś znajdzie się opcja rewolucyjna i pytanie o to, czy do tego horyzontu da się dojść drogą pokojową, czy potrzebne jest działanie rewolucyjne. I to nie jest wynalazek lewicy XX wieku, bo właściwie to samo można by powiedzieć o epoce oświecenia. $Z$ jednej strony pokładano nadzieje w edukacji, ale w sumie - dla bardzo wielu ówczesnych polityków i intelektualistów - praktyka dochodzenia do racjonalizmu wymagała oświeconego absolutyzmu, czyli krótko mówiąc, trzeba było zmusić ludzi do tego, aby ulegli obietnicy wolności. Oświecenie rosyjskie jest ewidentnie autorytarne, oświecenie pruskie jest autorytarne. Sami z siebie ludzie jakoś nie chcą w tę oświeconą przyszłość wskoczyć ochoczo i zracjonalizować się. Mniej więcej tyle o tej progresywistycznej optyce, o jej związku z radykalizmem. Ale z drugiej strony, Laclau zauważał coś takiego, że po upadku bloku wschod- 
niego, czyli po tych rewolucjach antykomunistycznych, antysocjalistycznych w Europie Wschodniej, i po załamaniu się obietnic lepszego socjalistycznego świata, w które bardzo wielu ludzi na Zachodzie wierzyło, wyborcy Francuskiej Partii Komunistycznej zaczęli głosować na Front Narodowy Le Pena. Czyli kompletnie odwrócili, o 180 stopni, swoje orientacje ideologiczne. Front Narodowy miał jednak, z ich punktu widzenia, jedną cechę wspólną z programem FPK - radykalizm. Czyli krótko mówiąc, dla niektórych osób myślących o polityce radykalizm jest ważniejszy od tego, czemu ten radykalizm ma służyć. Nie jest w żaden istotny sposób związany z kryterium prawica - lewica. Po prostu jeśli jest źle, to trzeba to zmieniać tu i teraz; a to, czy to będzie utopia narodowa, czy uniwersalistycznie internacjonalistyczna, to jest drugorzędna sprawa. Na pierwszym planie jest niecierpliwość i skłonność do posługiwania się radykalnymi środkami. To jest rzecz, która na poziomie analizy ideologii jakby znika albo wydaje się mniej widoczna, ale naprawdę można mieć do czynienia z rewolucyjnym konserwatyzmem w tym sensie, że żądamy po prostu lepszego świata i ten świat definiujemy nie w kategoriach tego, czego jeszcze nie było, tylko czegoś utraconego.

To jest bardzo ciekawe zjawisko, współcześnie chyba niesłychanie szerokie. Taki charakter ma ta słynna teza Trumpa, który chce Amerykę znowu uczynić wielką: Make America great again. Ostatnia książka Zygmunta Baumana ma tytuł Rerotopia. To, co nas dziś inspiruje, to nie utopia zorientowana na przyszłość. W tej diagnozie współczesnego świata patrzymy na rzeczywistość jako na coś, co utraciło swój sens, i poszukujemy tego sensu w przeszłości. I stąd ten dziwny związek odwoływania się do tradycyjnych wartości przy realizowaniu projektów społecznych, prowadzonych radykalnymi, rewolucyjnymi albo autorytarnymi metodami. Co oczywiście, masz rację, zaprzecza rozumieniu konserwatyzmu, które ukształtowało się w XVIII wieku, kiedy - w reakcji na radykalizm rewolucji - wiązano nadzieje $\mathrm{z}$ harmonijnym współżyciem, trwaniem przy tym, co dobre i unikaniem radykalnych zmian; bo trzeba dbać o to, co jest dobre, a nie psuć wszystkiego w imię czegoś, czego jeszcze nie ma. Więc mamy dziś zupełnie inne rozumienie konserwatyzmu. Ale to wszystko mieści się jeszcze w tej pierwszej diagnozie, czyli krótko mówiąc, to jest radykalizm zwrócony wstecz, który teoretycznie jest możliwy i wydaje się, że jest dziś dosyć powszechną zabawą.

Ale można na to popatrzeć jeszcze $\mathrm{z}$ innego punktu, z perspektywy długiego trwania idei progresywnych i radykalnych. Ogląd z tej perspektywy pokazuje, że na dobrą sprawę cały ten dyskurs progresywny, łącznie z oświeceniem, łącznie z socjalizmem, z wizjami komunizmu i tak dalej, jest kontynuacją idei chrześcijańskich, że jest on zagnieżdżony bardzo mocno 
w chrześcijańskim, dwuelementowym pragnieniu dobrego świata. To pragnienie dotyczy całego dyskursu pedagogiki jako działania publicznego. Koledzy z zachodniej Europy próbują dziś ten dyskurs rekonstruować jako Public Pedagogy, jako specyficzną wizję pedagogiki konstruującej wspólną rzeczywistość nie tylko w szkołach, ale w całej przestrzeni publicznej - u nas możemy po prostu mówić o pedagogice, bo taki poszerzony sposób myślenia o edukacji jest w naszej, środkowej części Europy dosyć powszechny. Wracając do chrześcijaństwa, chodzi o to, że - jak to ujmuje Daniel Tröhler - właściwie cały radykalizm pedagogiczny, który wiąże emancypację podmiotu $\mathrm{z}$ budową sprawiedliwego świata (i to są te dwa splecione ze sobą elementy, o których wspominałem), to znaczy wizja, zgodnie z którą edukacja ma służyć jednocześnie emancypacji jednostki, czy po prostu rozwojowi potencjału jednostki, a z drugiej strony, budowie dobrego społeczeństwa - obojętne znowu, jak to „dobre” społeczeństwo zdefiniujemy, jest cała lista terminów do podstawiania, socjalizm, liberalizm, społeczeństwo wiedzy czy katolickie państwo narodu polskiego - więc ten podwójny cel jest po prostu transformacją jednej i tej samej idei. W takiej perspektywie można widzieć pewną styczność, jakąś coincidentia oppositorum - gdzieś na krańcach radykalizmy lewicowe i prawicowe mogą mieć wspólne źródło, a jest nim kultura chrześcijańska. Zdaniem Tröhlera, ten ideał zakładający jednocześnie emancypację podmiotu i budowę sprawiedliwego społeczeństwa, to po prostu nowoczesna mutacja idei zbawienia duszy i budowy Królestwa Bożego na ziemi. A ujmując to historycznie - punktem początkowym zarówno nowoczesnej pedagogiki, jak i radykalnych ideologii społecznych, jest Reformacja. Reformacja te eschatologiczne wizje ściągnęła na ziemię, mówiąc w języku Agambena, sprofanowała je, w tym sensie, że oddała je zwykłym ludziom do użytku. I ze zwykłych ludzi, z każdej jednostki uczyniła osoby odpowiedzialne za realizację tych idei. Wszystkie zadania związane z dobrym życiem jednostki, $\mathrm{z}$ dobrym życiem wspólnotowym, stają się po prostu zadaniem realnych, tu i teraz żyjących ludzi, a nie eschatologicznym ideałem, który zstąpi na ziemię po dniach ostatnich, po końcu „tego" złego świata, gdy ten zostanie nareszcie w akcie Bożego gniewu zniszczony. W tym kontekście widać także, że idee rewolucyjne też są mutacją doktryny chrześcijańskiej, jakiegoś millenaryzmu, w tym sensie że marzą one o przyspieszeniu apokalipsy po to, aby Królestwo Boże na ziemi mogło nastąpić teraz, za naszego jeszcze życia. W każdym razie można sobie popatrzeć na ten dziwny splot radykalizmu politycznego, jakim jest socjalistyczna polityka PIS-u połączona z bardzo konserwatywną, retrotopiczną retoryką podszytą nacjonalizmem i chrześcijańskim fundamentalizmem, jako na aberrację, ale można też na to popatrzeć jako na - zaledwie 
- syndrom rozpadu tradycyjnych ram sortowania orientacji ideologicznych. $\mathrm{W}$ tym drugim oglądzie to, co robi PiS generalnie mieści się w tym samym co dotychczas polu możliwości. To nie znaczy, że to jest normalne z punktu widzenia naszych przyzwyczajeń, ale czort wie, czy to nie stanie się normalne za 10 lat i czy się ludzie z tym nie zdążą oswoić. Może powszechnie uznają, że bardzo konserwatywnie brzmiące doktryny - Polska od morza do morza, Wielka Rosja, America great again i tak dalej - to jedyna droga w przyszłość, bo to, co rysuje się jako „przyszłość przyszłości”, rozumiana jako świat inny od tych, które znamy, ma raczej coraz bardziej katastroficzny posmak. Ziemia się gotuje, globalne ocieplenie, migracje tak masowe, że nic ich nie zatrzyma i globalna wojna o wodę - i tak dalej, i tak dalej. Więc ta tęsknota do przeszłości jest pewnie jakimś na dłużej szykowanym lekarstwem, sposobem radzenia sobie ze strachem. To nie znaczy, że mi się to podoba, bo rekonstrukcja wszystkich naraz nacjonalizmów to najpewniejsza droga do wojny, i to szybciej niż nam się wydaje, ale można w tym szukać jakiejś upiornej, widmowej logiki.

K.S.: Coś jest na rzeczy, pamiętam, kiedy pojawił się dyskurs końca ideologii. Mamy po kilkudziesięciu latach powrót do tego samego. I to jest niesamowicie ciekawe, bo jak się spojrzy wstecz przez pryzmat tej koncepcji, okazuje się, że kategorie takie jak prawicowość czy lewicowość są przygodne, a podstawowym mechanizmem napędzającym historię jest mechanizm modernizacyjny, który dodatkowo nie rozpoczął się wraz zoświeceniem, tylko dużo wcześniej, wraz z chrześcijaństwem. Więc to zupełnie jakby przestrukturowuje też spojrzenie nie tylko na to, co jest, ale też na to, co było...

T.S.: Też mi się tak wydaje. W każdym razie dla mnie to jest strasznie ciekawa matryca i tak jak powiedziałem, wcale to nie znaczy, że jestem szczęśliwy z powodu powrotu nacjonalizmu. Wprost przeciwnie, uważam to za kompletną katastrofę i coś, co bardzo szybko nas może doprowadzić do wojny w bałkańskim stylu. Ale popatrzenie sobie na to w dłuższej perspektywie czasowej pozwala przynajmniej znaleźć jakiś typ racjonalności w tej irracjonalności.

K.S.: Chciałabym teraz dopytać o ten bardzo nam aktualny wątek. Nacjonalizm rozwinął się u nas z tak wielkim impetem, że właściwie ciągle należy dociekać i pytać, jak to się właściwie zaczęło. Jak to było i jest możliwe? Skąd ta powszechność? Pojawiają się oczywiście różne odpowiedzi, bazujące na różnych koncepcjach, różne próby tłumaczenia, jak do tego doszło po dramatycznych doświadczeniach XX wieku. Nie tylko w Polsce, bo problem jest raczej globalny. Dla mnie przekonujące jest spojrzenie przez pryzmat transformacji. Właściwa jej retoryka modernizacyjna, legitymizująca przemiany 
neoliberalne, była, jak się wydaje, ścieżką prowadzącą do tego, z czym obecnie mamy do czynienia. $Z$ drugiej strony są też ujęcia, które mówią, że nie jest to do końca wynik procesów ekonomicznych i generowanych przez nie nierówności społecznych i wykluczenia. Niektórzy, jak na przykład Gdula, nazywają to odrodzeniem się autorytaryzmu czy neoautorytaryzmem. Nie można jednak zaprzeczyć, że podczas transformacji coś poszło nie tak...

T.S.: Kiedy mówisz, że coś poszło „nie tak” po transformacji, to oczywiście można tu różnych rzeczy szukać. Poza czynnikami specyficznymi dla polskiej transformacji, moglibyśmy też szukać czegoś, co łączy skutki polskiej transformacji z tym, co się dzieje w kompletnie innych rzeczywistościach, jak Stany Zjednoczone, Włochy, nawet z pewnym opóźnieniem kraje skandynawskie. Te kraje nie przechodziły gwałtownej transformacji politycznej w polskim stylu, natomiast wszystkie przeszły pewnego rodzaju zmianę związaną ze sposobem rozumienia ekonomii i polityk społecznych, czyli wszystkie "trafil” neoliberalizm, mniej więcej w tym samym czasie co w Polsce. Około dziesięcioletnie opóźnienie tego procesu w Polsce w stosunku do USA, to nie jest dużo, tym bardziej, że neoliberalne reformy w Polsce zaczęły się jeszcze przed 1989 rokiem. Rząd Rakowskiego z Wilczkiem jako ministrem gospodarki to był już początek neoliberalizmu w Polsce, już wtedy zaczęło się transformowanie gospodarki w stronę prywatnej przedsiębiorczości i zredukowanie roli państwa. Przecież te słynne ustawy Wilczka regulujące życie gospodarcze to dzisiaj niedościgłe marzenie ludzi biznesu. Wszystko sprowadzono do zapisów na 3 stronach, jeśli się nie mylę, ale mniejsza z tym, czy to były strony 3 , czy 13 - nastąpiła absolutna redukcja regulacji, w dosłownym sensie deregulacja gospodarki i oddanie jej rozwoju prywatnym inicjatywom. I tu rzeczywiście można szukać wspólnego tła dla wielu krajów świata, dlatego że deregulacja oczywiście nasila proces dywersyfikacji, stratyfikacji ekonomicznej i budowania napięć pomiędzy, powiedzmy tradycyjnie, klasami społecznymi.

Zmierzam do tego, że wspólnym tłem obecnego zamieszania z ideologiami może być odwrót od neoliberalizmu, dodatkowo wzmacniany pewnego rodzaju pomyłką, czyli sklejeniem neoliberalizmu z liberalizmem „po prostu”. Bardzo wyraźnie widać to w dyskusjach - nie tylko politycznych, ale jeszcze wcześniej także pedagogicznych w Polsce, gdzie liberalizm jako dość złożona wizja etyczna, polityczna, pedagogiczna, ekonomiczna i filozoficzna, jest gładko redukowany do kombinacji neoliberalnego zarządzania wszystkim jak prywatnym biznesem, połączonym z konsumpcjonizmem i obyczajowym permisywizmem. W każdym razie, neoliberalizm może być tym wspólnym negatywnym punktem odniesienia. Inaczej mówiąc, te obecne powroty do 
myślenia konserwatywnego albo nacjonalistycznego, jako szczególnej jego postaci, mogą być próbą przeciwstawienia się, po pierwsze, globalizacji, bo globalizacja wiąże się z utratą kontroli nad warunkami życia ekonomicznego, i po drugie, redukcji roli państwa, redukcji roli tych instytucji, które są jako tako zarządzalne z perspektywy zwykłych obywateli. Kiedy robimy manifestację w Warszawie, to Warszawa być może się przejmie. Ale Waszyngton się tym nie przejmie. Na porozumienie waszyngtońskie nie wpłyniemy poprzez oddolne akcje społeczne takimi tradycyjnymi metodami obywatelskiego buntu. Chociaż oczywiście są instytucje i ruchy społeczne typu Avaaz, które próbują w skali globalnej tworzyć grupy nacisku i mają tam jakieś sukcesy, ale to nie jest sposób na to, żeby wszystkie problemy globalne upolitycznić i uczynić z nich przedmiot demokratycznej polityki. To jest też zresztą diagnoza Baumana, on o tym od dawna już mówił, że sposobem na zamknięcie tego rozziewu pomiędzy poczuciem bezpieczeństwa i polityką jest przywrócenie politycznej kontroli nad ekonomią. Gdyby opcje nacjonalistyczne okazały się konsekwentne i skuteczne, to znaczy gdyby państwa narodowe przejęły całkowitą kontrolę nad gospodarką, lud miałby przynajmniej jasno określonego adresata swojego buntu, jakąś instytucję $\mathrm{z}$ adresem i numerem telefonu. To jest chyba jakaś kusząca wizja dla klas zaangażowanych w konflikty na tle ekonomicznym, chociaż kompletnie mija się ona z realiami globalnej gospodarki. Ale może, tak na przyszłość, to tym gorzej dla tej gospodarki... Tymczasem ekonomia urwała się kompletnie z jakiegokolwiek wpływu społecznego. Nie mamy wpływu na decyzje wielkich korporacji, one są zupełnie autonomiczne. Bauman zresztą to świetnie opisywał jako trzecią jego zdaniem fazę uciekania kapitału. Nie chcę tego streszczać, za dużo czasu to zajmie, ale generalnie ta obecna faza ucieczki kapitału to jest ucieczka w przestrzeń między - narodową, z naciskiem na między, czyli kapitał nie podlega żadnym regulacjom żadnego określonego państwa, żadnej określonej wspólnoty politycznej. Tak się osadził, że jest kompletnie niezależny od tego, co jakiś rząd na jego temat powie, czy co jakiś protest społeczny czy polityczny chce mu zrobić. Jeśli zrobi się ciasno w jednym państwie, to ta sama firma tymi samymi aktywami będzie operować w innym państwie i sobie świetnie poradzi, po prostu funkcjonuje w takiej przestrzeni, która nie podlega kontroli politycznej. I teza Baumana była taka, że trzeba zrobić coś, żebyśmy ten ponadnarodowy czy międzynarodowy kapitał poddali kontroli społecznej, czyli w domyśle coś w rodzaju międzynarodowego rządu, jakieś porozumienie, jakaś polityczna struktura, która nie miałaby charakteru narodowego tylko globalny i zajmowała się relacjami między ekonomią i polityką: skutki ekologiczne, skutki ekonomiczne dla krajów, które są eks- 
ploatowane przez różne globalne korporacje, bo są dostarczycielami jakichś tanich minerałów do produkcji jakichś drogich gadżetów... Nie ma możliwości zbilansowania skutków społecznych, skutków ekonomicznych gospodarki i jakiejś politycznej kontroli, takiej jaką dawały na przykład państwa narodowe, gdzie można było wymusić jakieś prawo ochrony pracy, można było wprowadzić progresywne skale podatkowe, można było po prostu sterować tymi procesami. Lepiej czy gorzej, ale jednak ludzie mieli poczucie, że ma się możliwość kontroli. I to mi się wydaje jest jeden z elementów, które pomagają zrozumieć, skąd ten nagły napad tęsknoty do państw narodowych. Po prostu nie umiemy sobie wyobrazić, że doprowadzimy do jakiejś skutecznej kontroli kapitału w tej ulotnej sferze pomiędzy kontrolą państw. W każdym razie jest to jakoś racjonalny wymiar zwrotu ku państwom i sceptycyzmu wobec niekontrolowanych globalnych przepływów, z brakiem kontroli nad tym, co nas prędzej czy później bezpośrednio dotyka.

Natomiast z punktu widzenia tej grupy teorii, która akcentowała rolę retoryki, symboliczne reprezentacje itak dalej, no to problem nacjonalizmu oczywiście wpisuje się w perspektywę, o której wspominałaś wcześniej, transformacja, to co sobie zrobiliśmy przez te lata po 1989 roku. Niektórzy socjologowie i filozofowie, Małgorzata Jacyno na przykład, od dłuższego czasu zwracali uwagę na to, że bardzo brakuje nam symbolicznej reprezentacji wspólnoty w tych procesach społecznych. Sprowadziliśmy wszystko do efektywności, mamy być przedsiębiorczy, a Unia Europejska ma nam dać kasę...

K.S.: ...a my mamy dać Unii Europejskiej wartości...

T.S.: ...tak. Wy nam dacie kasę, a my Wam wartości, przy czym jak się popatrzy na te nasze wartości, no to właśnie rodzina, krewni, znajomi, cztery fury, dwa domy, i po prostu czym więcej, tym lepiej. Zrobiliśmy się albo pazerni, albo nacjonalistyczni. Jakby zabrakło nam sensu, takiego egzystencjalnego, a także jakichś ram wspólnotowości. To wszystko może być w tle tego nagłego głodu symboli i silnych, udramatyzowanych symboli wspólnoty. Te symbole, które się w efekcie tego głodu pojawiają, są niemal atawistyczne, pozbawione jakiejś finezji i skromności, patetyczne i nekrofilne. Raczej pogańskie niż chrześcijańskie, nawet jeśli na chrześcijańskich znakach budowane. Można mieć wrażenie, że religijność, zaprzężona do narodowych rytuałów, jakoś się zawinęła, stała się wsobna, oderwała się od istotnych treści. Zamiast otwierać dusze ku transcendencji, tworzy duszne, ciasne wspólnoty, wystraszone wszystkim, co otwarte. Najbardziej dramatycznie to widać w niezdolności do miłości bliźniego - w kwestii uchodźców po prostu. Po prostu Polska nie jest krajem chrześcijańskim w etycznym rozumieniu. 
Natomiast ludzie potrzebują i używają instytucji Kościoła jako miejsca, gdzie się po prostu bywa razem w celu wykonania rytualnych gestów, które dają poczucie przynależności do jednej przestrzeni. To oczywiście ważne, ale kompletnie wsobne. Mam wrażenie, że nacjonalizm zawłaszczył w Polsce chrześcijaństwo. I jest to długotrwały proces, który teraz chyba uległ intensyfikacji i przyspieszeniu. Dyskurs narodowy z Polski nigdy nie zniknął, na jakiś czas został przytłumiony, ale właściwie od XIX wieku jest cały z nami. Wbrew temu co tak chętnie dzisiaj ludzie mówią o okresie PRL-u, edukacja była wtedy zdecydowanie nacjonalistyczna. Cały czas Sienkiewicz na liście lektur, cały czas sprawa Polski jako rozdartej między koniecznością podporządkowania się Sowietom i strachowi przed Niemcami. Główny wątek w tamtym czasie to uzasadnianie obecności wojsk radzieckich w Polsce przez stale podsycany strach przed Niemcami, przed tym, że wrócą do Wrocławia, Gdańska i tak dalej. Poczucie wrogości świata zewnętrznego było nieustannie budowane jako uzasadnienie dla sowieckiej kolonizacji. A dzisiaj? Komuna padła już dawno, z Niemcami gramy formalnie po tej samej stronie barykady, ale cały czas te lęki bardzo łatwo jest aktywizować dla doraźnych celów. Dziadek z Wehrmachtu, der Onet i tym podobne figury są niemal fundamentem retorycznych strategii prawicowej propagandy.

A wracając do koncepcji teoretycznych, o których rozmawiamy, to tutaj podstawowym wymiarem jest właśnie symboliczna reprezentacja całości, zapotrzebowanie na reprezentowanie całości, która jest w dosłownym wymiarze niereprezentowalna. Nie rozumiemy, czym jest Polska ani polskość, nigdy tego nie zdefiniujemy, a musimy chcieć rozumieć - i ten problem może być rozwiązany wyłącznie przy pomocy symboli, figur retorycznych, czegoś, co wywołuje emocje, a nie domaga się racjonalizacji. Kłopot polega na tym, że pomimo iż to wydaje się sugerować całkowitą pustkę, a stąd zupełną dowolność takich reprezentacji, to naprawdę nie jest wszystko jedno, jaki one mają wyraz.

K.S.: Ale to też oznacza, że szkoła, bardziej niż nam się wydawało, nie wykonała swojej pracy, właściwie zupełnie wycofując się z zadania budowania wspólnego świata. Nie wiem, czy „wspólne” to jest odpowiednie słowo, ale na pewno swoją publiczną rolę zdecydowanie zapoznała. Mam wrażanie, że wynika to $\mathrm{z}$ jednej strony $\mathrm{z}$ zaniedbania, i z drugiej, z niedoceniania tego, że przekaz szkolny przynosi jednak jakieś efekty. Po pierwsze, wspomniany przez Ciebie, niewrażliwy na kontekst dyskurs edukacji patriotycznej, która po prostu sobie była, którą nikt bardziej poważnie się nie zajmował, a w każdym razie nie zastanawiał się nad jej możliwymi konsekwencjami. A po drugie, zupełne zawieszenie tego, że edukacja coś ma konstruować. Koncentracja na 
testach, egzaminach i eliminacja wartości, czegoś istotnego i sensotwórczego, co mogłoby zostać „podniesione do godności Rzeczy”, mówiąc językiem Laclau, spowodowało, że ta rola została przesunięta w inne miejsce i zaczęła przyjmować karykaturalne wręcz formy. Czyli nieprzepracowana edukacja patriotyczna, poszatkowana, bez spójności, do której się podchodziło z dystansem i przymrużeniem oka oraz wyeliminowanie zadania świadomego budowania wspólnego świata, czy konstruowania mniej ekskluzywnego uniwersum symbolicznego, dającego szansę na tożsamościową identyfikację.

T.S.: Na pewno czegoś tutaj zabrakło, ale czego, to do dzisiaj nie wiemy. $\mathrm{Z}$ całą pewnością nawalił projekt budowy nowej tożsamości europejskiej. To można było zrobić i to jakoś próbowano robić, ale oczywiście tego się nie da zadekretować na zasadzie zalecenia miłości do symboli i tak dalej. Chociaż to także jest obecne i próbowano to robić oczywiście, flagi Unii Europejskiej i Oda do Radości, to bardzo piękne rzeczy, ale trudno wywołać silną emocjonalną identyfikację na zasadzie zadekretowania, że „to jest nasze”, „to przestrzeń wspólna”. Ten proces budowania tożsamości trwa, on został jakoś zaprojektowany i nie jest czymś bezsensownym. To wielowymiarowy proces i po części to działa. To, że mamy wspólne symbole, że mamy europejskie paszporty, stwarza jakieś ramy „bycia z Europy”. Tego doświadcza się wyraźnie jednak tylko wtedy, gdy wyjeżdża się z Europy, gdy w USA słyszymy „Where are you from in Europe?” - wtedy zauważamy, że Europa w oglądzie zewnętrznym jest jednak całością; jednak takie doświadczenie jest niedostępne na masową skalę. Wewnątrz można tego tak wyraźnie nie odczuć.

Od strony wewnętrznej z kolei programy integracji, takie jak Erasmus, mają służyć temu, żeby eliminować wrogość pomiędzy poszczególnymi krajami. Stąd nacisk na wymianę, na to, że w każdym projekcie europejskim muszą być partnerzy spoza najbliższego otoczenia, nie znaczy tylko z „własnej” części Europy. Jak ktoś z Francji chce aplikować o pieniądze Unii, to nie może zrobić projektu tylko z Belgami i Niemcami, ale musi wciągnąć jeszcze kogoś z Europy Wschodniej, bo inaczej tych pieniędzy nie dostanie. Wiele jest takich mechanizmów.

K.S.: Tak, problem jednak w tym, że wszystko ostatecznie zostało sprowadzone do procedur. Trudno tu o identyfikację emocjonalną czy afektywną inwestycję w dyskurs Unii Europejskiej. Przekonująco pisał o tym Yannis Stavrakakis, który zwracał uwagę na pozbawiony wymiaru afektywnego projekt europejskiej tożsamości, którego egzemplifikacją mogą być tak "palące” problemy, jak przysłowiowa już prostota ogórka czy krzywizna banana. Tym, co funkcjonuje w wyobraźni na temat Unii Europejskiej są zatem procedury, do których należy się dostosować, jeśli chce się być jej częścią. I tyle. Mamy 
flagę Unii, bo musimy. Nic poza tym. Nastawienie na proceduralność przyniosło zatem odwrotny efekt od zamierzonego. Unię Europejską traktuje się dokładnie tak, jak narzuca to jej dyskurs. Czyli całkowicie instrumentalnie i pragmatycznie.

T.S.: To oczywiście irytujące. Ale być może jest to kwestia tempa. Nie zdajemy sobie sprawy, ilu procedurom i regulacjom podobnym do norm krzywizny banana podlegamy bez Unii Europejskiej. Normy istnieją od średniowiecza i nikt ich już prawie nie zauważa. Tu problem jest taki, że w ciągu kilku lat dostosowujemy się do norm, które powstawały przez kilkadziesiąt. Niektóre normy rzeczywiście wyglądają absurdalnie, ale już nie pamiętamy, że musieliśmy się kiedyś nauczyć centymetrów i kilogramów zamiast łokci, kop i funtów, i że kiedyś w każdym mieście była inna godzina, bo wyznaczał ją zegar na wieży ratusza ustawiany na oko według słońca. Kiedyś mój kolega z USA bardzo się dziwił, że w całej Europie mamy $230 \mathrm{~V}$ w gniazdkach; nie wyobrażał sobie, jak można było coś takiego wszystkim narzucić. Więc to są po prostu mechanizmy koordynacyjne, które w przypadku tych nieszczęsnych owoców chyba mówią, które nadają się do masowego transportu w standardowych opakowaniach dostosowanych do wielkości kontenerów. Próbuję zgadywać oczywiście :) No i jasne, że to wszytko wkurza, ale ja nie widzę tu jakiegoś dramatycznego problemu.

K.S.: Oczywiście, tego typu normy istnieją od bardzo dawna, ale mówiąc przekornie, rzadko się zdarza, żeby w tak bezpośredni i jawny sposób wymagano tożsamościowej identyfikacji z nimi. Zgadzam się, że proces konstruowania tożsamości jest zwykle bardzo długi i zachodzi w sposób niezauważony, ale pojawia się tu jeszcze jeden, nieco odmienny problem. Projekt Unii Europejskiej może być, przynajmniej przez część społeczeństwa, postrzegany jako kolonizacja, jako intruzja w obszar tego, co bliskie, a co może opiera się na innych zasadach. Nawet jeśli nie do końca wiemy, o jakie zasady tu chodzi, to jednak samo pojawienie się dyskursu powoduje, że nagle zdajemy sobie $\mathrm{z}$ nich sprawę i stają się one dla nas bardzo ważne.

T.S.: Tak, członkostwo w Unii bywa postrzegane jako forma kolonizacji, wymaga ono zrzeczenia się jakiejś dozy autonomii na rzecz koordynacji $\mathrm{z}$ innymi krajami. Ale to jest dobrowolny proces, mający w Polsce mimo wszystko wciąż duże poparcie, więc może pojęcie kolonizacji nie jest tu najtrafniejsze.

A w kwestii identyfikacji - zdecydowanie tutaj czegoś zabrakło. Ale mi się wydaje, że ten deficyt identyfikacji może być jeszcze poważniejszej natury. Może po prostu nie da się jej osiągnąć na sposób podobny do identyfikacji narodowych, bo może nie chcemy sobie fundować takiego podobieństwa. 
Może chodzi o to, że za flagę Unii Europejskiej nikt jeszcze nie umarł. Brak afektywnego i symbolicznego ciężaru symboli UE może wiązać się z tym, że Europa jako całość nie wystąpiła po jednej stronie jakiegoś konfliktu, w którym mogłyby się rozegrać jakieś krwawe rytuały tożsamościowe. Klasyczna triada nacjonalizmu - ziemia, krew, tożsamość - w przypadku UE nie ma zapachu krwi. Może przez to nie mamy poczucia, że to jest warte życia. I stąd brak sentymentu, bo nie ma tu mitycznych wymiarów tożsamości: heroicznej śmierci, zdrady, ludobójstwa i tak dalej. UE to po prostu racjonalna koalicja państw i gospodarek, która póki co zadziałała genialnie w jednym obszarze zgodnym z jej założeniami - czyli po prostu zapobiegła kolejnej wojnie w Europie, przynajmniej między krajami do UE należącymi. A taki długi pokój między Niemcami i Francją podobno nie zdarzył się jeszcze nigdy w historii - no i pokój jest nudny; inaczej mówiąc, między Niemcami i Francją „nic się nie dzieje", i to rzeczywiście nie brzmi romantycznie. I pewnie dlatego nie pamiętamy, że UE właśnie po to została stworzona, że te wszystkie koordynacje i związki ekonomiczne to tylko droga, a nie cel. Że Schumann i wszyscy założyciele tego projektu przede wszystkim nie chcieli dopuścić do kolejnej wojny w Europie - a pomysłem na jej zablokowanie było wytworzenie tak silnej integracji gospodarek, i to na początku właśnie w tych sektorach, które są związane z przemysłami wojennymi, węglem i stalą, by wojna była nie do pomyślenia. I to się udało. Problem więc raczej polega na tym - i dlatego mówię, że sprawa może być gorsza i poważniejsza - że nie umiemy sobie wyobrazić tożsamości bez wojny. Tożsamości grupowe najłatwiej się przecież krystalizują w walce przeciw komuś innemu. I dopóki nie ma konfliktu, który zjednoczy nas po jednej stronie barykady, dopóki ludzie z dwóch krajów nie zostaną razem pochowani, bo zabił ich ktoś trzeci, takie dwa kraje nie wytworzą tożsamości w narodowym stylu. Nie będzie poczucia, że ta tożsamość coś znaczy, że jest czymś dosłownie śmiertelnie poważnym i że na jej cześć warto wykrzykiwać takie rzeczy, jakie wykrzykują nacjonaliści. Narody wykąpały się w swojej krwi, od XIX wieku, kiedy zostały wymyślone, miały do tego mnóstwo okazji. Natomiast projekt ponadnarodowej wspólnoty europejskiej, póki co, jest projektem przeciwstawiającym się potrzebie takich "kąpieli”, temu typowi identyfikacji, a na to miejsce nikt nic równie silnego nie jest w stanie wymyślić. Wszystko jest słabsze od karnawału zabijania i heroizmu umierania, i to z jakichś ponurych powodów ludzi cały czas kręci i perwersyjnie do tego tęsknią. Więc pewnie zostaniemy z tą słabą tożsamością i nadal będziemy narzekać na banany i ogórki. 
K.S.: Z drugiej strony, nie mówimy o klasowym wymiarze zjawisk takich jak możliwe kanały i środki identyfikacji. Gdzieś to umknęło. A być może nacjonalizm ma jakieś klasowe współrzędne...

T.S.: Ma, mi się wydaje, że ma...

K.S.: Być może w projekcie tożsamościowym Unii Europejskiej, w takiej formie, w jakiej był obecny i wdrażany w Polsce, było miejsce na afektywną inwestycję, ale zarezerwowaną dla jednej klasy społecznej. Mówiąc wprost, był to projekt skierowany do klasy średniej, która była w tym dyskursie jednocześnie konstruowana. Podobnie zresztą jak projekt obywatelski. Innymi słowy, estetyka Unii Europejskiej, wspólnoty, wspólnej flagi, wspólnych procedur mogła trafić tylko do części polskiego społeczeństwa. Projekt nowej klasy średniej był projektem klasy kosmopolitycznej, otwartej na Zachód, dobrze znającej języki i czującej się wszędzie jak u siebie. Klasy, która nie ma korzeni, bo jest efektem potransformacyjnego projektu ugruntowanego przede wszystkim w rynku. Dla innych klas poniżej średniej, dla tych, którzy na transformacji nie skorzystali, a nawet przeciwnie, stali się jej ofiarami, „wspólna” Europa była miejscem, w którym można poprawić swój byt, ale z którym niekoniecznie można się wiązać emocjonalnie, czy usensowniać swoje życie za jego pośrednictwem. Jestem daleka od tego, żeby piętnować to zjawisko - materialnego podejścia do Unii - podkreślam jedynie, że jest to naturalna konsekwencja zawieszania kwestii klasowych wodniesieniu do projektowanych procesów tożsamościowych i identyfikacyjnych. Innymi słowy, pomijanie klasowych sposobów na afektywne inwestowanie, a tym samym symboliczne wykluczenie z tego dyskursu całej masy ludzi, naturalnie doprowadziło do jego odrzucenia. W efekcie Unia Europejska nie miała możliwości dostarczać poczucia sensu. Dyskurs Unii nie miał szans trafić do części społeczeństwa, które, mówiąc wprost, było z niego skutecznie wykluczone. Podobnie z rodzimymi projektami tożsamościowymi. Tymczasem dyskurs narodowy i retoryka wojny pojawiają się między innymi właśnie jako próba restytucji sensu. Edukacja bez wątpienia poniosła porażkę również na tym polu, pokazując części społeczeństwu, że rzeczywistość jest dla kogoś innego i dla kogoś innego może stanowić źródło sensu. Weźmy przykład listopadowych marszów niepodległości, organizowanych od kilku lat przez ONR. Pomijając wszystko inne, uderzające jest poczucie władzy nad rzeczywistością, jaką wydają się wykazywać ich uczestnicy. Mocy - teraz rzeczywistość jest nasza, ulica jest nasza. Być może ci ludzie przez większość swojego życia nie czuli się tutaj w ogóle jak u siebie.

T.S.: Pewnie masz rację, pewnie to tak dokładnie wygląda. Projekt europejski chyba bardziej odpowiada stylom życia, sposobom funkcjonowania 
poznawczego i typowi pracy klasy średniej. Niekoniecznie jednak klasy średniej z punktu widzenia stratyfikacji dochodowych, bo jak się patrzy na to, kto popiera PiS i inne prawicowe formacje, to jest tam masa ludzi, którzy są prywatnymi przedsiębiorcami, którzy bardzo dobrze zarabiają; jak pan Jakubiak, który ma dobrze prosperujące browary. To nie jest kwestia biedy, a w każdym razie nie tylko kwestia biedy. Ta „europejska” klasa średnia to może raczej frakcja tej klasy, która jest związana $z$ instytucjami publicznymi, z pracą w edukacji, w sztuce, nauce, czyli ludzie - oczywiście nie wszyscy - którzy żyją w przestrzeni idei, a przez to w przestrzeni międzyalbo ponadnarodowej. Wymiana idei jest dla nich czymś oczywistym. Jako akademikom trudno nam sobie wyobrazić, że nie będziemy mieć swobody zapraszania ludzi z zagranicy albo wyjeżdżania do nich, czytania literatury, która oni publikują, że ktoś nam powie, że to niepolskie i będzie zabronione. Tak bywało w PRL, ale większość aktywnych zawodowo ludzi tego nie pamięta i dziś jest to poza horyzontem wyobraźni. A mówiąc nawiasem, może bardzo szybko wrócić. Natomiast dla ludzi, którzy prowadzą własną działalność gospodarczą i którzy opanowali znaczną część rynku krajowego, globalizacja i konkurencja międzynarodowa staje się zagrożeniem. Więc dla nich zamknięcie granic mogłoby być postrzegane jako ratowanie własnego (i pewnie powiedzieliby, że polskiego) biznesu. Czyli niekoniecznie dystynkcje statusu społeczno-ekonomicznego muszą odgrywać tu dominującą rolę. Nacjonalistów może być wielu wśród elit finansowych. Ale generalnie się zgadzam, że prawdopodobnie coś takiego jak klasowe ulokowanie nacjonalizmu może mieć miejsce. A przynajmniej tak sobie to wyobrażają rządzący, sądząc po retoryce PiS. Kaczyński często odwołuje się do ludzi, którzy zostali zmarginalizowani poprzez procesy prywatyzacyjne i globalizacyjne. Pojęcie narodu jest o tyle poręczne w tego typu kampaniach, że ignoruje to, czy ktoś jest biedny, czy bogaty, czy ma dom, czy jest bezdomny, i tak dalej. Pojęcie narodu to pojęcie wyobrażonej, symbolicznej wspólnoty, zwykle w ramach określonego terytorium. Jeśli ktoś mówi w określonym języku i urodził się „tutaj”, to jest częścią tej wspólnoty po prostu. Bez względu na to, czy jest bezdomny, czy ma cztery domy. $\mathrm{W}$ tym sensie jest to bardzo dobry materiał dla totalizujących kampanii politycznych. W dodatku łatwo manipulowalny. Wystarczy pokazać, że mamy ciągłe zagrożenie zewnętrzne, a jeszcze lepiej - zewnętrznie opłacane, ale ukryte wewnątrz, w mediach, uczelniach, wśród proeuropejskich elit, i mamy potrójny efekt: strach, gniew i poczucie własnej mocy w jednym.

K.S.: Tak, ale wydaje mi się, że dyskurs ten jest niewykluczający wewnętrznie $w$ jeszcze innym sensie. Ponownie nawiązując do porażki dys- 
kursu obywatelskości oraz europejskiej obywatelskości. Projekty tożsamościowe promowane po 1989 roku opierały się na kryteriach przynależności. Zgodnie z tym ludzie zobligowani byli wykonywać jakiś wysiłek. Aby być obywatelem i obywatelem Europy należało spełnić określone standardy, nawet natury estetycznej. Trzeba było wykonać jakiś dodatkowy wysiłek, dla niektórych pozbawiony sensu: iść na wybory, działać w stowarzyszeniach i organizacjach pozarządowych, udzielać się, myśleć w określony sposób o rzeczywistości i tak dalej. Innymi słowy, trzeba było pracować nad własną tożsamością. Dodatkowo tożsamości te były konstruowane w taki sposób, że wydawały się być czymś narzuconym, czy doświadczanym jako narzucane z zewnątrz. Tymczasem dyskurs narodowościowy, narodu, jest wewnętrznie inkluzyjny. Bycie częścią takiej wspólnoty nie wymaga właściwie żadnych kompetencji, żadnych dodatkowych umiejętności, które trzeba nabyć, czy to językowych, czy to poznawczych, czy też związanych ze stylem życia. Innymi słowy, wystarczy być. Dyskurs modernizacyjny w odniesieniu do tożsamości jest przez ludzi odrzucany, o ile ta tożsamość naturalnie, czyli klasowo, do nich nie pasuje. I zadziwiające jest, że nikt sobie nie zdawał z tego sprawy. Że dopiero post factum być może stało się to oczywiste.

T.S.: Myślę, że z tej „wymagającej” części Twojej rekonstrukcji ludzie sobie zdawali z tego sprawę, na 100\% w 90. latach, kiedy dyskusja nad budową (dosłownie) społeczeństwa obywatelskiego była intensywnie obecna. Ewidentnie był to bardzo mozolnie i świadomie konstruowany dyskurs pedagogiczny, który obejmował także kwestie czysto ekonomiczne w rodzaju wprowadzenia podatku dochodowego - właśnie jako zabiegu pedagogicznego. Argumentacja? Jeśli ludzie będą płacić podatki i podpisywać to swoim nazwiskiem, to będą czuć się w mocy czegoś żądać i wchodzić w relacje z państwem jako partnerzy, a nie jako poddani tego państwa...

K.S.: Tak, zdecydowanie był to dyskurs pedagogiczny. Węgierscy socjolodzy, Gil Eyal, Ivan Szelenyi i Eleanor R. Townsley, autorzy książki Making Capitalism Without Capitalists. The New Ruling Elites in Eastern Europe, która nie wiem dlaczego nie została przetłumaczona na język polski, a jest bez wątpienia jedną z ważniejszych analiz transformacji w krajach Europy środkowowschodniej, stwierdzili, że obecny w projekcie transformacji zamysł edukacyjny przebiegał dwutorowo. $Z$ jednej strony, była to edukacja publiczna z edukacją obywatelską na czele, $\mathrm{z}$ drugiej - rynek. W obu przypadkach chodziło o wyuczenie odpowiednich dla gospodarki kapitalistycznej zachowań, sposobów myślenia i w efekcie tożsamości...

T.S.: Tak! Taki pedagogiczny charakter miał też na przykład projekt dotyczący przekształcania spółdzielni mieszkaniowych i parcelacji ich własności 
na indywidualną własność hipoteczną. On też miał uzasadnienie pedagogiczne. Chodziło o świadomość, że jest się czegoś właścicielem, w związku z tym własność jest dobra. Dodatkowo, własność mieszkania to miał być pierwszy kapitał, przy pomocy którego można rozpocząć wędrówkę do gospodarki rynkowej. Mogę to mieszkanie sprzedać w momencie, gdy jest ono coś warte i zainwestować w coś innego. Krótko mówiąc, sensu to nie miało z punktu widzenia samego zamieszkiwania, rozbijało też logikę spółdzielczości, natomiast miało właśnie uczyć zachowań rynkowych, zachowań właściwych dla społeczeństwa kapitalistycznego.

K.S.: Dodatkowo, cała ta infantylizująca retoryka okołotransformacyjna, która sprowadzała ludzi do uczniów. Ciągłe powtarzanie, że dopiero się uczymy demokracji, że demokracja jest w powijakach, że nie dorośliśmy do demokracji, nie dorośliśmy do gospodarki rynkowej, i tak dalej.

T.S.: Wracając jeszcze do projektu europejskiej tożsamości. Zauważ jednak jeszcze jedną rzecz, że ten nieudany projekt konstruowania europejskiej świadomości paradoksalnie, jak sie okazuje, wydaje się być jakoś skuteczny, gdy pojawia się świadomość europejskości wśród nacjonalistów. To jest groteskowe, ale nacjonaliści w Europie mają poczucie tworzenia wspólnoty europejskiej - jednak w momencie, kiedy do gry wchodzi dyskurs rasy. Kiedy mówią „biała Europa”, to nie przeszkadza to niemieckim, polskim, szwedzkim, duńskim, francuskim i rosyjskim nacjonalistom iść we wspólnym marszu; nie przeszkadza obca narodowość, która powinna przecież stanowić podstawowe kryterium konstruowania relacji wróg - swój. Kiedy nacjonaliści mówią o białej Europie, ich nacjonalizm schodzi na drugi plan. Są w pełni solidarni. Międzynarodowy nacjonalizm jest jakąś groteskową konstrukcją, on powinien być z definicji niemożliwy - ale naprawdę powstaje, jako forma dyskursu rasistowskiego.

K.S.: Pozostając przy problemie konstruowania wroga w dychotomii my - oni, chciałabym zapytać o kwestie teoretyczne, a konkretnie o polityczność teorii Laclau rozumianej $w$ analogii do opisywanych przez Ciebie polityczności teorii edukacyjnych. Czy teoria wykorzystana jako narzędzie analityczne sama nie wywołuje efektów politycznych? Czy w związku z tym nie należałoby myśleć raczej przeciw teorii Laclau, której zasadniczy trzon opiera się na koncepcji wykluczenia i konstruowaniu wrogów, jeśli chcemy myśleć o wspólnocie nieekskluzywnej?

T.S.: Czy zmierzasz do tego, że ta teoria podtrzymuje dążenia do uznawania konfliktu za fundament organizacji świata?

K.S.: ...i tworzenia podziałów my - oni. Nawet jeśli w oparciu o nią da się wprowadzić element normatywny, to na zasadzie tej samej logiki. 
T.S.: Wydaje mi się, że ta teoria ma potężny walor... Generalnie jest to teoria strukturalistyczna, mimo że Laclau próbuje się od strukturalizmu odżegnywać. Ale ona ma wszystkie słabe i mocne strony metodologii strukturalistycznej. Ponieważ teoria pokazuje strukturę konstruowania hegemonii bez treściowego oceniania kryteriów, na podstawie których ta hegemonia została skonstruowana - to niemal prosi się o zarzut "normatywnego deficytu”, o którym mówiliśmy. Laclau jednak nie akcentuje konfliktu tak mocno, chociaż pierwszy moment tworzenia nowej identyfikacji wymaga zdefiniowania „constitutive outslide”, czyli jednak wykluczenia, czegoś, co pozwoli określić granice tożsamości. Można to w zasadzie sprowadzić do Heglowskiej różnicy (znowu wbrew Laclau, który od Hegla odżegnuje się jeszcze silniej). Silniej to jednak widać u Chantall Mouffe. Mouffe odwołuje się bezpośrednio do Carla Schmitta i krytykuje lewicę za to, że nie wykorzystała lekcji, którą przerobili faszyści. Schmitt był przecież szefem korporacji prawników III Rzeszy i nie da się tego nie pamiętać. Nawiasem mówiąc, dzisiaj jest czytany przez Jarosława Kaczyńskiego, i jak widać po efektach, czytany uważnie. W ujęciu Schmitta, konflikt zaczyna się tam, gdzie pojawia się opozycja swój - wróg. Dopóki nie ma antagonizmu, nie mówimy o polityczności, nie mówi się o relacjach typu politycznego. Niemal wszyscy politologiczni eksperci kupują takie rozumienie polityki jako absolutnie podstawową, oczywistą sprawę. Widać to w medialnych ocenach kampanii wyborczych - nawet kiedy mówią o kampaniach partii, których nie znoszą, są w stanie je doceniać, jeśli komuś sprytnie uda się wykreować figurę wroga. To sprowadza się do cynicznej socjotechniki i jest to niesłychanie dyskusyjne dla myślenia o wspólnotach politycznych. Ja uparcie wracam, chociaż niezbyt ekspansywnie, bo to się raczej we wzmiankach i przypisach u mnie pojawia, do rozumienia polityki, która bazuje na antycznej etymologii tego słowa: do polis, czyli miasta, wspólnoty. Polityka to konstruowanie przestrzeni wspólnej. To może, ale nie musi zakładać antagonizmu wobec innej wspólnoty. Dlatego tak ważne jest dla mnie rozróżnianie dyskursu słabnącej, więdnącej III RP z tym, co obecnie wyłoniło się jako strategia PiS. Wracamy tu do kwestii nacjonalizmu. Chodzi mi o to, że - pomimo iż mój ulubiony Laclau konsekwentnie twierdzi, że symbole organizujące wspólnotę są semantycznie puste - to jednak nie są one, w sensie performatywnym i zatem etycznym obojętne. Tak jakoś się dziwnie składa, że pojęcie narodu jest zawsze definiowane w opozycji do innych narodów. Że ono jest zawsze definiowane w przestrzeni antagonizmu. To najlepiej widać nie w samej semantyce tego pojęcia, gdzie naród to ci, co się narodzili gdzieś tam albo z kogoś tam, czyli że jest to grupa definiowana przez wspólnych przodków albo wspólne terytorium, tylko w jego historycznych - Laclau 
powiedziałby: w ontycznych - konfiguracjach. Kiedy pojawiły się narody? To był XIX wiek, konflikty wielkich wielokulturowych imperiów, i w efekcie tych konfliktów początek rozpadu tych imperiów. Gdy zaczęły słabnąć, pojawiły się wewnętrzne tarcia między tworzącymi je grupami etnicznymi, wizje niepodległości, powstania i wojny narodów przeciw narodom. Naprawdę narody krystalizowały się w wojnach, w powstaniach przeciw wielkim imperiom - a gdy imperia się rozpadły, niemal natychmiast w wojnach między sobą, naród przeciw narodowi. Świetnie to widać w nacjonalistycznej publicystyce, na przykład u Mariana Reutta, na którego z uwielbieniem powołuje się ONR. To był jeden z założycieli polskiej falangi. W książeczce Reutta o wychowaniu narodowym z 1939 roku punktem wyjścia jest zdanie, że świat składa się $\mathrm{z}$ narodów prowadzących wojny $\mathrm{z}$ innymi narodami. Jednoznacznie, do istoty narodu należy tutaj to, że naród prowadzi wojny z innymi narodami. Dlatego, równie jednoznacznie, i dla przedwojennej falangi, i dla ONR, i dla obecnej władzy PiS, wychowanie narodowe jest wychowaniem militarnym. Krótko, dyskurs narodowy to dyskurs wojny. Jeśli więc dziś puste znaczenie „społeczeństwa obywatelskiego" (puste, bo używamy tego pojęcia jak zaklęcia, nie definiując go - tylko dopóki jest puste może pełnić rolę inkluzywną) jest systematycznie, uparcie i konsekwentnie zastępowane innym, podobnie pustym, i z tego samego powodu niezdefiniowanym pojęciem narodu, to - pomimo ontologicznej pustki obu tych figur - na poziomie ontycznym, na poziomie pragmatyki ich używania i jej performatywnych skutków, kompletnie nie jest obojętne, które z nich zdominuje publiczną wyobraźnię i zagarnie publiczne emocje. Jakoś nie słyszałem, żeby pojęcie społeczeństwa wikłało się w konotacje wojny z innymi społeczeństwami. Dyskurs konstruowania społeczeństwa to dyskurs konstruowania przestrzeni wspólnej, wspólnoty, społem, razem. Polityczny problem bycia razem to pytanie, jak zorganizować własną przestrzeń mimo tego, że każde z nas jest inne i ma swoje prywatne albo grupowe potrzeby, ambicje czy interesy. Zupełnie niekonieczna jest do tego wojna $\mathrm{z}$ innymi społeczeństwami, na innych terytoriach albo - jak mamy to w socjologii Znanieckiego - nawet na tym samym terytorium, próbującymi wytwarzać swoje polis. Po prostu społeczeństwa powstają jako agregacja, jako forma samoorganizacji grup i jednostek, które chcą albo muszą żyć razem, bo są na jednym terenie i muszą znaleźć formę koordynacji, organizacji wspólnego życia. Gdzieś tu się odzywa biblijne „miłuj swojego sąsiada” - nie dlatego, że jest taki sam jak ty (co zakłada koncepcja narodu, tożsamość urodzenia, naród-rodzina); musisz go miłować chociaż jest inny - bo inaczej nie da się żyć. Znowu biblijnie, z tej samej przypowieści - lepszym sąsiadem, członkiem mojego społeczeństwa, czy „bliźnim”, jak wciąż 
wolimy mówić w Polsce, może być etnicznie mi obcy facet z Samarii, niż tu urodzony i mówiący tym samym językiem „swój”, mijający mnie obojętnie.

Wracając do polityczności teorii Laclau. W swoich późnych, i dla mnie najważniejszych tekstach Laclau trzyma duży dystans do konkretnych ideologicznych czy politycznych identyfikacji, na poziomie teorii oczywiście. Kiedy jeszcze mieliśmy z nim okazję rozmawiać, to nie było żadnych wątpliwości, że interesowała go lewica; natomiast teoria jest strukturalistyczna, czyli jakoś uniwersalistyczna, niemal zimna, pokazuje logikę i racjonalność systemu społecznego (zauważmy w tytule jego bodaj najważniejszej książki - ROZUM populistyczny) - chociaż sama ta logika jest „nieracjonalna” w tym sensie, że odwołuje się raczej do retoryki niż do logiki pojęciowych reprezentacji. I rzeczywiście może się tu pojawić jakiegoś rodzaju deficyt, ale on nie ma charakteru normatywnego, jak widzi to Critchley. Ja bym powiedział, że jest to raczej ontologiczna kwestia, która u Laclau wiąże się z ostrym sprzeciwem wobec logiki Heglowskiej. Critchley domagał się wyprowadzania konkretnych wniosków dla polityki lewicowej; Laclau tego unikał, mówiąc mniej więcej tyle, że takich wniosków nie wyprowadza się na poziomie teorii, że jest to problem konkretnych kontekstów, normatywności osadzonej w określonych warunkach społecznych. Ja sam w tym miejscu czytania Laclau zaczynam mieć wątpliwości, zaczynam mieć jakieś heglowskie pokusy. Chodzi mi o to, że konsekwentne trzymanie się wizji pustych znaczących jako symboli reprezentujących całość jest piękne i przekonujące, ale pojawiają się wątpliwości, gdy patrzy się na to z pedagogicznego punktu widzenia. Laclau nie musiał tego robić, bo analizował historycznie zachodzące procesy politycznego konstruowania tożsamości. Patrzył tą swoją strukturalną matrycą na procesy, które były prawicowe, lewicowe, nacjonalistyczne albo autorytarnie konserwatywne - i widział ich wspólną logikę. To było dla niego i fascynujące (zresztą komu to nie imponuje?), i wystarczające. Natomiast z mojego punktu widzenia, kiedy próbowałem przymierzać teorię Laclau do myślenia pedagogicznego, musiałem brać pod uwagę, że, jak już wcześniej mówiłem, w szkołach możemy wytwarzać sztuczne światy, które nie są ściśle i funkcjonalnie związane $z$ systemem normatywnym aktualnie istniejących społeczeństw. I wręcz można powiedzieć, że tego się ludzie od edukacji spodziewają, że to ma być taka mutagenna instytucja, że tak powiem, wprowadzająca różnicę, wprowadzająca dystans do tego co jest. Inaczej, po prostu, byłaby ontologicznie zbędna, byłaby prostą socjalizacją. W takiej sytuacji chciałoby się mieć jakąś miarę, jakieś kryterium oceniania, jakie skutki przyniosą te akurat puste znaczące, wykorzystane w procesie pedagogicznego formowania tożsamości. Jak powiedziałem, „hamulec” w postaci specyficznych systemów 
normatywnych, limitujących zakres znaczeń przypisywanych określonym znaczącym, może w przypadku edukacji nie zadziałać, bowiem edukacja może być skierowana przeciw takim normatywnym regułom. Na przykład może promować zachowania kooperacyjne w rywalizacyjnym społeczeństwie kapitalistycznym, być jego etycznie motywowaną korektą. O, i tu pojawia się pokusa, żeby patrzeć na te figury retoryczne, które reprezentują totalność, czyli puste znaczące w ujęciu Laclau, przez pryzmat pewnych dialektyk, które one mogą wywoływać; może skromniej mówiąc, nie tak całkiem po heglowsku, przez pryzmat relacji do innych znaczących, które funkcjonują na tym samym poziomie, w tych samych „zbiorach” czy repertuarach dostępnych nam pustych symboli. Czyli traktować je troszeczkę jak pojęcia. Próbowałem coś takiego zrobić...

K.S.: Pisałeś o rezerwuarze pustych znaczących...

T.S.: Tak, edukacja może być postrzegana jako tworzenie rezerwuaru pustych znaczących. I dla mnie niezwykle ciekawym projektem, którego nie zrobię pewnie, byłoby popatrzenie sobie właśnie na same te rezerwuary, czyli na pule pojęć, czy raczej terminów, które funkcjonują w dyskursie publicznym jako potencjalnie puste znaczące, nadające się do tożsamościowych inwestycji - i co szczególnie ważne, na wzajemne relacje między nimi. Czyli chodziłoby o to, żeby teraz przeprosić się trochę z Heglem i popatrzeć sobie na nie tak, jakby były pojęciami, które mają swoją logikę relacji z innymi pojęciami. I ten przykład, o którym zacząłem wcześniej mówić, o różnicy między pojęciem społeczeństwa i pojęciem narodu jako prezentacji nieosiągalnej pełni, zapowiada próby takich analiz. Wydaje mi się to dosyć istotne. Jak wspomniałem, tożsamość budowana na pojęciu narodu jakoś zakłada konfliktowe relacje $\mathrm{z}$ innymi narodami. O tym przesądza chyba ta kontyngentna, normatywna i ontyczna warstwa tego terminu, inaczej mówiąc, specyfika kontekstu historycznego, w jakim to pojęcie było pierwotnie używane. Ale być może jest też coś w samym sposobie definiowania tych pojęć: wracając do tego przykładu - samo definiowanie albo przez odniesienia do narodzin (naród, natus, natura, narodzenie, rodzina), albo do bycia razem tu oto (społeczeństwo, społem, wspólnota, coś robić razem) wywołuje jednak jakieś logiczne konsekwencje, jakieś wykluczenia i możliwe kierunki uogólnień. Więc te skądinąd puste znaczące wikłają się w relacje z innymi skądinąd pustymi znaczącymi, tworzą jakieś semantyczne sieci, w których pewne relacje są bardziej prawdopodobne niż inne relacje, pewne antagonizmy bardziej nieuniknione niż inne antagonizmy, i tak dalej. Pojęcie społeczeństwa wydaje mi się słabsze pod względem uruchamiania antagonizmów niż pojęcie narodu, i stąd - w etycznym sensie - jest pedagogicznie „lepszym” 
pustym znaczącym niż pojęcie narodu. Jak świetnie to zauważyłaś, pisałaś o tym i kiedyś o tym rozmawialiśmy, tam też są wykluczenia. Mówię teraz o obywatelskości i społeczeństwie obywatelskim; tylko one są skierowane jakby do wnętrza i do własnej struktury. Czyli żeby być członkiem społeczeństwa trzeba spełniać pewne warunki, no właśnie trochę się postarać, jak przed chwileczką o tym mówiłaś, a w narodzie „się jest” z racji narodzenia tu, a nie gdzie indziej. To społeczne raczej niż narodowe myślenie też mi się wydaje być refleksem etyki protestanckiej, która jest dość rygorystyczna jeśli chodzi o normatywne warunki przynależności do wspólnoty. W tej perspektywie nie wystarczy po prostu być, jak mówiłaś o polskiej tradycji kulturowej; być może ta różnica ma właśnie charakter religijny, jest efektem tego, że Polska nie łyknęła protestanckiej reformacji. A nie łyknęła może właśnie dlatego, że się Polakom nie chciało, bo szlachta, która decydowała o tym, co tu się będzie działo, miała już dobre życie zagwarantowane - żyli swobodnie i nie musieli się starać wobec jakichś normatywnych oczekiwań na drodze do Królestwa Bożego na ziemi. Oni już je mieli, złota wolność, uroki życia poczciwego, dostatek i marmurowe nagrobki z trumiennym portretem na wieczną chwałę i pamiątkę. A reszta nie miała nic do gadania i żaden normatywny rygoryzm, żadne starania nic by nie dały. Tu tylko nędza - a nadzieja na Królestwo Boże w tamtym świecie, z łaski Pana, ze sprawiedliwego odwrócenia losu jak w przypowieści o wielbłądzie i igielnym uchu, a nie w efekcie starań.

A wracając do tych pedagogicznych pytań o puste znaczące, to w tekstach, w których zaczynałem podejmować takie próby „pedagogicznego szacowania pustki" angażowanej w formowaniu tożsamości, stawiałem sobie pytanie o to, kto po drodze zostanie wykluczony, aby tożsamość mogła się uformować. To wynika z teorii Laclau, ta konieczność ustanowienia „konstytutywnego zewnętrza", czyli po prostu wykluczenia jako pierwszego warunku tworzenia relacji równości, czy ekwiwalencji w jego języku. Czyli, jeśli uruchamiamy jakieś znaczące jako oczekiwany horyzont identyfikacji, w naszym przykładzie - robimy sobie transformację pojęcia społeczeństwa w pojęcie narodu, to znaczy, że zmieniamy logikę wykluczeń. $Z$ tej wewnętrznej, o której pisałaś w przypadku społeczeństwa obywatelskiego (czyli już nie antyobywatel, którego genialnie zidentyfikowałaś w tej roli w podręczniku WOS) na zewnętrzną (czyli Niemiec, Rosjanin albo Żyd, albo Arab). Krótko mówiąc, ktoś z zewnątrz ma stanowić płaszczyznę krystalizacji tego co społeczne.

Podstawowa w wymiarze pedagogicznym różnica jest taka, że o ile przy tej wewnętrznej logice wykluczenia można się starać, to znaczy jest jakaś - realna czy nierealna - droga, wizja dorastania do obywatelstwa (na przykład obojętny na cierpienie ofiary napadu Żyd mógłby się nauczyć zachowywać 
jak samarytanin, po to przecież była ta przypowieść), to przy tej zewnętrznej logice wykluczeń nie ma takiej możliwości. Wręcz przeciwnie, jeżeli Niemiec postara się i zasymiluje, to tym bardziej będzie groźny i tym szybciej stanie się ofiarą dążeń do czystości narodowego samookreślenia. Tak jak zasymilowani Żydzi byli bardziej skandalicznym, bo ukrytym i przez to oczywiście zdradzieckim i przebiegłym casusem dla antysemityzmu niż Żydzi żyjący w gettach i wyznający ortodoksyjną wersję judaizmu. Ortodoksi byli po prostu egzotyczni, obcy i kropka, a ktoś zasymilowany, nie wiadomo czy to Żyd, czy Polak, to dopiero było zagrożenie. Inaczej mówiąc, w etnicznie pojmowanym narodzie nie ma dróg inkluzji. Tu się trzeba urodzić, ale jeszcze i tak będzie się poddawanym rozmaitym testom na "prawdziwość" tego narodzenia.

Rozgadałem się o tej relacji naród - społeczeństwo, bo ona wskazuje, że puste znaczące tak nie do końca są puste. Jednak zakładają one jakieś konsekwencje, wywołują jakoś odmienne dążenia do krystalizacji, do ujednoznacznienia tego, w imię czego jesteśmy razem - właśnie przez to, że zakładają odmienne wykluczenia. Czyli, krótko mówiąc, to kryterium etyczne - jakiego typu wykluczenia mogą być spodziewane przy użyciu tego czy innego rodzaju pojęć - wydaje się być ważnym dopełnieniem teorii Laclau $\mathrm{w}$ analizach pedagogicznych konstrukcji tożsamości. A wracając do Twojego wyjściowego pytania, w jakim sensie teoria Laclau jest polityczna, to kłopot $\mathrm{z}$ odpowiedzią jest taki, że Laclau próbuje budować coś uniwersalnego. $\mathrm{W}$ tym sensie jego teoria może być tłumaczona nie tylko na strategie dla lewicy, co przecież było powodem, dla którego powstała fantastyczna książka o hegemonii, napisana razem z Mouffe, ale i na strategie dla jakiegokolwiek projektu politycznej tożsamości, monarchistycznego, nacjonalistycznego czy komunistycznego - struktura hegemonii jest taka sama. W punkcie wyjścia była pisana na użytek lewicy, ale nie wydaje mi się lewicowa w tym senesie, żeby miała reprezentować na przykład interes emancypacyjny zdominowanych grup społecznych. Rancière jest chyba pod tym względem bardziej bezpośredni.

K.S.: Chciałabym jeszcze kontynuować kwestię normatywności i przejść do problemu uznawanego przez Ciebie za istotę edukacji, czyli projekcji nowych światów. W tekście Punk Theory piszesz o exodusie - kategoria ta pojawia się na końcu tekstu. Czy jest to jakaś alternatywa dla edukacji, używając języka Gerta Biesty, kwalifikującej i socjalizującej, a więc związanej z nabywaniem, kształtowaniem czy pielęgnowaniem tożsamości? Niezwykle ciekawe jest ujęcie edukacji rozumianej w kategoriach tworzenia dystansu, czyli niejako oduczającej, wyprowadzającej. Idea Punk Theory pojawia się 
w kontekście bardzo specyficznego momentu, wktórym przyszłość nie napawa optymizmem, w efekcie czego pozostawanie w teraźniejszości wydaje się czymś naturalnym - No Future! Czym w takim razie taka edukacja jest? Czy exodus to jest edukacja tworząca dystans - czy nie jest to edukacja?

T.S.: To jest edukacja. To nawet etymologicznie jest edukacja, bo słowo educere oznacza wyprowadzanie, a nie wprowadzanie. To jest wyciąganie skądś. Bez względu na to, czy jest to platońska jaskinia, czy dom...

K.S.: Jan Masschelein mówił o etymologii słowa pedagog, oznaczającego niewolnika, który wyprowadzał z domu, a nie prowadził do szkoły...

T.S.: No właśnie, ten negatywny wymiar jest tutaj niezwykle istotny. Tak, to jest jeden z podstawowych wymiarów edukacji. Teraz, jeżeli popatrzymy sobie na edukację jako uwikłaną w dominujące porządki normatywne, które - jak piszę we wspomnianym przez Ciebie tekście - dziś wydają się krystalizować w jakiejś gotowości do wojny, to jasne, że jednym z podstawowych zadań etycznej edukacji jest budowanie dystansu i niezgody. Pojęcie exodusu pożyczyłem od Lewisa, ale widzę je tu w bardziej dramatyczny sposób niż on proponował; trzymając się metafor $\mathrm{z}$ tamtego tekstu - chodzi o bardziej punkowo, a mniej „klasztornie” pojmowany exodus. A dramatyczność tej figury polega na tym, że być może cały ten okres, o którym rozmawiamy, integracji europejskiej i prób budowania słabej, nieantagonistycznej europejskiej tożsamości, to tylko przerwa między wojnami. To przecież mamy „na końcu języka”, tylko nikt nie chce tego mówić. Punkowe „no future” oznacza tu po prostu odmowę wojny, odmowę udziału w szukaniu linii okopów - po to, żeby przedłużyć czas liminalności, życia w tej kruchej strefie niedookreślenia, bez tożsamości. No i buntu. Sam exodus nie wystarczy - trzeba wrzeszczeć, że idzie wojna i że się nie zgadzamy.

W pewnym sensie to nic nowego. Ten tekst jest dość dziwny, dla mnie również, na granicy tego co robię „serio”, ale czuję jakby był dla mnie powrotem do czegoś od zawsze mi bliskiego, czyli na styk sceptycyzmu i krytyczności. Zawsze czułem dystans i nieufność wobec wszystkiego, co jest mi wkręcane czy wciskane. Ale tym razem to jest kwestia polityczna, to może mieć znaczenie w sytuacji masowego entuzjazmu, który dzisiaj buduje się w dyskursie narodowym. I właśnie teraz dystans, exodus, czyli odmowa udziału w rysującym się porządku wojny (tak, w tym tekście piszę, że to wojna jest „porządkiem”, tak to bowiem widzą prący do niej nacjonaliści - wojna jest jasną strukturą swój-wróg, czyli pełną krystalizacją tożsamości) - ale łączony z apologią chaosu i krzykliwym szukaniem nowych i odmiennych od tych wojennych połączeń. Teoria jak pogo dance, edukacja jako psucie dobrego samopoczucia ludzi, którzy wiedzą, kto swój, a kto wróg. Czuję przymus 
wchodzenia ze studentami w rozmowy o nacjonalizmie, czytania z nimi tekstów o narodzie i wychowaniu militarnym, i o tym, że wojna ma kształtować charaktery. I trzeba w pewnym momencie zadać pytanie - czyje charaktery? Tych co zabijają, czy tych co są zabijani? Trzeba doprowadzić te pojęcia do absurdu, wyjść poza te "porządkujące” dychotomie. Powiedzmy, że w tym tekście o punku i exodusie chodzi o dekonstrukcję - w bardzo politycznym sensie. Bo to naprawdę jest piękne i uwodzące, jak się maszeruje, i się śpiewa, i jeszcze policja nas bije. Coraz wyraźniej to właśnie staje się normą naszego świata, a nie aberracją. To jest to, co się wyłania jako nasza przyszłość - i stąd no future i exodus. Zależało mi, żeby podjąć wątki dystansu, troski o świat i widzenia edukacji - takiej właśnie zdystansowanej - jako siły emancypującej i zmieniającej świat, podobnie jak w tekstach bliskich mi autorów, ale jednocześnie nie chciałem, żeby to miało wymiar, który nazwałem sobie klasztornym, odizolowana medytacja w skupieniu na rzeczach, które interesują. Zależało mi, żeby rozumienie dystansu nie zamknęło się w logice pięknego swoją drogą projektu, w który u nas jest zaangażowany Piotr Zamojski. Zamiast rekonstruowania klimatu konserwatywnej edukacji elit, raczej ironiczny, delikatnie mówiąc, dystans do tożsamości, o którym w ramach odmowy udziału w przyszłości wrzeszczały dzieciaki z ruchu punk. Kilka dni temu wróciliśmy z Mają z Irlandii, byliśmy na seminarium SCAPE, i Gert Biesta mnie o ten tekst też zagadnął. Zwrócił mi uwagę na coś ważnego, co w nim pominąłem: że punk ma jeszcze jeden bardzo ciekawy pedagogiczny wymiar, że jest jakby z gruntu demokratyczny w tym sensie, że każdy może robić muzykę i każdy ma prawo wyjść na scenę. I dopiero potem się okazuje, co z tego zostało, co było śmieciem naprawdę, co było wygłupem, i co się z tego może wykrystalizować jako coś wartościowego. To bardzo ważna dziś perspektywa. Naprawdę nikt nie ma pomysłu na przyszłość, na horyzoncie same katastrofy, i jedyne co przychodzi ludziom do głowy to szykowanie się do wojny. Wszystkie logiki i wszystkie ideologie, wszystkie instytucje i partie polityczne mogą zaraz być w ten wojenny porządek wessane kompletnie. Stąd odmowa: no future, punk i pogo - nie tylko exodus, ale też energia tamtego buntu po to, żeby w chaosie mówienia i myślenia miało szansę urodzić się coś nieprzewidywalnego (bo wszystko, co dziś przewidywalne, to właśnie wojna) i na tyle mocnego, by za cholerę nie dać się włączyć w porządek wojny. Taka może rozpaczliwa próba wyjścia z przyszłości. I to nie jest czas na postkrytyczność chyba.

K.S.: Chciałabym zadać jeszcze jedno pytanie, które powinno się pojawić wcześniej. Wrócę na moment do kwestii fenomenu PiS. Mówiłeś o strategiczności działań Kaczyńskiego, używającego kategorii narodu i w związku 
z tym popularności PiS wśród nie tylko pokrzywdzonych przez system czy przez transformację, ale również tych, którzy się na transformacji dorobili. Chciałabym zapytać o logikę tej strategii, której bez wątpienia nie było wcześniej w polskiej polityce. Jest to bowiem partia, która potrafi pokazać, że odpowiada na potrzeby ludzi. Innymi słowy, PiS jest partią, która potrafi pokazać, że aktywnie staje w obronie pokrzywdzonych i jest partią „odwetu” i zadośćuczynienia. Takie ujęcie polityki PiS jest podejmowane w koncepcji neoautorytaryzmu. Niektórzy piszą o jej wyborcach jako kierowanych wewnętrzną potrzebą zemsty. Chcemy, żeby ktoś pokazał nam, że jest po naszej stronie i może zrobić krzywdę tym, którzy nas skrzywdzili. Wydaje się, że konstruując taki dyskurs, odpowiedzieli na potrzebę ludzi do bycia włączonym - a więc w opozycji do tego, co konstruował wcześniej dyskurs społeczeństwa w wersji liberalnej, elit demokratycznych, czy liberalnych elit demokratycznych - a więc poczucia, że jest się w domu, pod czyjąś opieką. Być może dyskurs ten więcej ludziom daje niż zabiera. Być może ludzie poczuli się zmęczeni retoryką ciągłego oczekiwania, ciągłego myślenia w kategoriach przyszłościowych, polityką odbierania, wymagania, cięcia, okrajania - właśnie taką protestancką - że trzeba oddalić w czasie korzyści, a tu i teraz zacisnąć pasa. Wydaje się, że PiS przedstawia politykę w kategoriach tu i teraz: tu i teraz możemy pobić waszych wrogów, że tu i teraz możemy pociągnąć kogoś do odpowiedzialności, i tak dalej.

T.S.: To chyba dość trafne. W tym co mówiłaś spotykają się dwa wątki. Jeden - może o tym w ten sposób nie myślałem, ale jak o tym mówiłaś to to się jakoś tak fajnie zarysowało - że można popatrzeć na sukces PiS jako analogię do sukcesu kontrreformacji w Polsce. Jako zmęczenie tym, że jest tak na serio, że te przykazania są takie poważne, Bóg taki surowy i milczący, i tak dalej. Czyli to, co teraz przeżywamy, byłoby kontrreformacyjne. Zresztą ciekawe, że Tusk jako Kaszuba, jako człowiek z Pomorza reprezentuje tę etykę protestancką, a Kaczyński jako człowiek z Warszawy tę kontrreformacyjną. I to jest jeden wymiar, w którym to chyba jakoś gra. Drugi to wymiar potocznie rozumianego populizmu, czyli „my jesteśmy u siebie”, to nasz punkt widzenia jest najważniejszy. Taki populizm może wiązać się z autorytaryzmem, ale też z wizją jakiejś feudalnej rzeczywistości, w której biedni chłopi rządzeni są przez wszechmocnych panów. Zresztą to się dosłownie pojawiało w wypowiedziach Kaczyńskiego, gdy zirytowany odpowiadał komuś w dyskusji w parlamencie, że tak, jesteśmy panami, ale jesteśmy dobrymi panami. Naprawdę! Taka figura dobrego pana odbiera ludziom sprawstwo, ale otacza ich opieką. To fundamentalny gest zerwania z tym, co tutaj sobie nazywamy protestancką wizją odpowiedzialności, albo z oświeceniową wizją odpowie- 
dzialności. Przeciw temu protestanckiemu i Kantowskiemu oświeceniowemu mówieniu o dojrzałości i odpowiedzialności za sprawy świata mamy dobrych panów, którzy biorą na siebie rolę odpowiedzialnych za cały świat i na siebie biorą odpowiedzialność za to, że tak jak „lubimy” możemy dalej palić węglem, bo to nasz węgiel $i$ to nie jest nasze ostatnie słowo, i mamy prawo dusić się w smrodzie swojskiego węgla. Żeby nam było miło, nie denerwują nas problemami i w ukryciu ustalają, co jest dla nas dobre i w trzy godziny podejmują decyzje w parlamencie. To jest dopiero infantylizacja. O ile liberałowie wysyłali nas do szkoły, to PiS trzyma nas w przedszkolu. Co najwyżej w grupie średniaków. To naprawdę jest jakiś powrót do politycznego dzieciństwa. Kiedyś Joan Copjec, która jest ze Słowenii, z tej szkoły co Žižek, pisała tekst o polityce właśnie zmarłego George’a Busha. Opisywała tę politykę z perspektywy psychoanalitycznej figury ojca, który jest nieznośny, ciągle nas zawodzi, jest jakimś hulaszczym typem, któremu wszystko wolno; wkurzająca figura, która budzi nienawiść, ale jednocześnie z drugiej strony jest to figura ojca opiekuńczego, który narzuca normatywny porządek, który zakazuje nam wszystkiego, na co sam sobie pozwala. Copjec analizowała wybory w Stanach Zjednoczonych jako oscylację pomiędzy tymi dwiema figurami ojcostwa: tęsknota do normatywności każe nam znaleźć kogoś, w kogo zainwestujemy nasze zaufanie, marzenie, że to on, że wreszcie ktoś się nami zajmie - a po paru latach patrzymy na jego występki, na taką rozbuchaną pańskość, agresywność i pazerność, na samowolę i bezwstyd, i pojawia się fala nienawiści. Rytuał wyborczy staje się aktem rewolucyjnej egzekucji, niszczymy ojca narodu. Symbolicznie ścinamy mu głowę i w tym geście ojcobójstwa na chwilę stajemy się dorośli. Po to, żeby w tym samym momencie, z obywatelską odpowiedzialnością znaleźć sobie następnego ojczulka. To, co robi PiS chyba się w taką logikę wpisuje; oni rzeczywiście wchodzą w dyskurs ojca, dobrego pana. I tu by pasował ten opis odpłaty: tata wam pokaże. Ojczulek dla nas taki dobry, ale taki bezwzględny dla wrogów ludu, nie da skrzywdzić i wyeliminuje wszystko, co dzieciom może wejść w drogę. W tej analizie Copjec jest jednak bezwzględna logika - taka figura ojca musi zawieść, nikt nie jest w stanie spełnić takich oczekiwań, i prawdopodobnie upadek odbędzie się w tej samej logice, czyli skandalu, zawodu, zdrady i w rezultacie rytualnego ojcobójstwa. Co ciekawe, w przypadku tej partii to się toczy w dramatycznie szybkim tempie. Te fazy są jakby bardzo przyspieszone, ta erozja jest bardzo gwałtowna, co wcale nie znaczy, że PiS szybko odejdzie od władzy - świetnie nauczyli się wypychać jeden kryzys kolejnym kryzysem, wywołują je niemal co tydzień, w czysto Orwellowskiej, ale znacznie szybciej niż w „1984” przebiegającej sekwencji kolejnych fikcyjnych wojen. W końcu 
chyba objawi się rzeczywiście czysty autorytaryzm, bez żadnych obietnic, kierowany wyłącznie strachem przed linczem, przed rozliczeniem.

K.S.: Czyli wracając do edukacji, sposobem na to, z czym mamy obecnie do czynienia jest właśnie edukacja powodująca dystans? Edukacja, która zawiesza wszelkie tożsamościowe pretensje, ale która wiąże się nadal z ideą krytycznego myślenia.

T.S.: Jeśli edukacja, to chyba taka, tak.

K.S.: Więc jaka właściwie to jest edukacja?

T.S.: Na pewno nadal krytyczna. $\mathrm{W}$ tej chwili wydaje mi się, że pole dla edukacji krytycznej jest potężne.

K.S.: Przepraszam, że wejdę w słowo, ale muszę nawiązać do tendencji teoretycznych, które obecnie są bardzo silne weuropejskiej filozofii edukacji. Pedagogika krytyczna jest dzisiaj bez wątpienia pod, inspirowanym Rancière'em, teoretycznym ostrzałem ze strony badaczy takich jak Gert Biesta, Jan Masschelein, czy u nas Piotr Zamojski. Sam Rancière zresztą, w krytyce tradycji krytycznej w socjologii i edukacji jest bardzo przekonujący. Czyli jeżeli edukacja krytyczna to taka sama czy jednak inna?

T.S.: Ojej, to jest następny potężny temat. Ja mam poczucie, że część tego krytycyzmu przeciwko teorii krytycznej ma charakter taki, powiedziałbym, doraźny. Na pewno można teorii krytycznej zarzucić to, co zresztą już w latach 80 . się pojawiało, w znanym artykule Ellsworth na przykład, i co jest w pełni zgodne z krytyką Rancière’a, czyli jakiś typ poczucia wyższości emancypujących pedagogów i jakiś powiązany z tym rodzaj elitaryzmu. $\mathrm{Na}$ pewno jednak znaczący pozostaje postulat kształtowania dystansu albo po prostu stwarzania przestrzeni dla dystansu i świadomości krytycznej. To jest bardzo istotne obecnie. Natomiast rzeczywiście można patrzeć teraz inaczej na konteksty, w których to działa. W tamtej klasycznej pedagogice krytycznej problemem była niemożliwość udziału w debacie publicznej, wymuszone milczenie zdominowanych; stąd „empowerment”, polityka głosu i tak dalej. Dzisiaj polityczny horyzont wyznacza nie niemożność, a ogromną łatwość mówienia. W epoce Facebooka zmorą tego świata stało się to, że każdy ma prawo mówić, że wszystkie głosy stają się równoważne, i że jednocześnie nie ma możliwości racjonalnej argumentacji i nikt nie ponosi za słowa odpowiedzialności. Coś się w ich rezultacie dzieje, ale daleko, nie znam człowieka, a w ogóle to już jestem offline. Ogromnej wagi nabiera więc taka faza krytycznej edukacji, którą mocno akcentował Giroux: mówienie „własnym głosem" jest politycznie bez sensu, jeśli nie podlega wykształconej teoretyzacji, jeśli nie włączy się to $\mathrm{w}$ jakieś myślenie zracjonalizowane, które może wejść w orbitę dyskursu publicznego jako pozycja, która jednak wymaga konfron- 
tacji z innymi pozycjami, i jest przedstawiona tak, że w ogóle wiadomo, jak z nią podjąć dyskusję, która daje szansę jakiejś negocjacyjnej praktyki.

K.S.: Czyli bardziej oświecenie niż marksizm?

T.S.: Tak. Tak, zdecydowanie. No dobrze, czyli sprowadzając to do rdzenia - tak, przydałoby się nowe oświecenie. Wydaje mi się, że zaczyna być zauważalny jakiś deficyt rozumu publicznego jako pewnej instancji, do której można się odwoływać w sytuacjach konfliktu populizmów, bo w tej samej mamy po prostu setki populizmów na tej samej płaszczyźnie.

K.S.: Postprawda, Fake news...

T.S.: Tak. Nawzajem się dyskredytujących. Wszystko jest fałszywe, wszystko jest ideologiczne, wszystko jest nieprawdą. Ten deficyt rozumu jest wręcz bolesny, i w tym sensie jest to jakieś pole dla działalności edukacyjnej. Czyli z jednej strony jakaś nieufność wobec tych wszystkich emocjonalnych strategii budowania wspólnoty, dyskursu narodowego, dyskursu populistycznego, dyskursu białej rasy, czy islamskiego fundamentalizmu, czy chrześcijańskiego fundamentalizmu. Tego jest pełno po prostu, co trzy metry to jakiś fundamentalizm i trzeba do tego jakiś dystans budować. Punk theory jest o tym. Z drugiej strony jednak zdolność do racjonalnej praktyki, racjonalnego podejmowania decyzji. Póki co, nikt jej nie oczekuje, to jest dramat, że nie ma nawet miejsca, w którym to by się do czegokolwiek mogło przydać, bo nie ma takiej platformy, na której ktoś by czekał na racjonalne konfrontacje. Bo sama racjonalność zostałaby już uznana za fake news. I sami się do tego przyczyniliśmy. Tekst Latoura, który Piotr Zamojski nam kiedyś zaproponował do dyskusji, pokazuje, że po stronie zwolenników teorii krytycznej też pojawia się refleksja, że niestety odnieśliśmy sukces. Że wszyscy mogą być dziś krytyczni, upełnomocnieni do mówienia tego, co myślą i fundamentalnie nie wierzą żadnym autorytetom. Nauczyliśmy ludzi marksistowskiej krytyki ideologii i dystansu do oświeceniowej nauki, więc szczepionki to spisek koncernów farmaceutycznych. Jakoś trzeba wrócić do rozumu, dosłownie i w przenośni. No i przydałaby się jakaś wizjonerska polityka, która by stworzyła płaszczyznę rozmawiania o rzeczywistości. A na razie to wygląda tak, jakbyśmy już się pogodzili, że racjonalnych decyzji nie będzie i dojdzie do globalnej wojny: wszyscy się na to gotują i wszyscy oczekują, że nastąpi, więc pewnie zgodnie z upiorną logiką historii nastąpi. To jest najprostszy, i niestety sprawdzony wielokrotnie scenariusz, który zresetuje wzajemne pretensje, sprowadzi je do absurdu zabijania dla samego zabijania, i dopiero gdy po tej fazie przyjdzie jakieś wyczerpanie i otrzeźwienie, zacznie się budowanie od nowa. Na razie zaplątaliśmy się w coś, co wygląda na sytuację bez wyjścia. I z tej właśnie logiki trzeba się wyrwać. Znowu punk: God save the 
Queen, the fascist Regime. Ale mi się mimo wszystko nie chce wierzyć w to, że nie będziemy w stanie... ciągle jest jakaś nadzieja, że jakaś forma bycia razem, niekoniecznie w logice wojujących ze sobą narodów i religii, gdzieś się przebije przez to zaczadzenie i że da się jeszcze trochę pożyć; i ponaprawiać te deficyty racjonalizmu.

K.S.: Dziękuję, myślę, że to dobre podsumowanie naszej rozmowy.

\section{SUMMARY}

The Ontologies of the Political, The Politics of Identification. Prof. Tomasz Szkudlarek's conversation with dr. Karolina Starego. The conversation concerns the political in education and educational theory. It addresses the dimensions of identity and identification. The key questions, concerning the performative nature of educational rhetoric and the ontology of educational theory are discussed in the perspective of Ernesto Laclau's concept of the political, and in the context of contemporary social issues - the legacy of post-communist transformation, the threat of authoritarianism and the fascist tendencies visible in the modern public sphere.

KEYWORDS: the political in education, ontology of the political, Ernesto Laclau, rhetorics, identification 